\title{
24. MAFIC CLASTS IN SERPENTINE SEAMOUNTS: PETROLOGY AND GEOCHEMISTRY OF A DIVERSE CRUSTAL SUITE FROM THE OUTER MARIANA FOREARC ${ }^{1}$
}

\author{
Lynn E. Johnson²
}

\begin{abstract}
Clasts of metamorphosed mafic igneous rock of diverse composition were recovered in two drill sites on a serpentine mud volcano in the outer Mariana forearc during Ocean Drilling Program Leg 125. These clasts are xenolithic fragments that have been entrained in the rising serpentine mud, and make up less that $9 \%$ of the total rock recovered at Sites 778 and 779 . Most samples are metabasalt or metadiabase, although one clast of possible boninite and one cumulate gabbro were recovered.

On the basis of trace element signatures, samples are interpreted to represent both arc-derived and mid-ocean ridge-derived compositions. Rocks with extremely low $\mathrm{TiO}_{2}(<0.3 \mathrm{wt} \%)$ and $\mathrm{Zr}(<30 \mathrm{ppm})$ are similar to boninite series rocks. Samples with low $\mathrm{TiO}_{2}(<0.9 \mathrm{wt} \%)$ and $\mathrm{Zr}(<50 \mathrm{ppm})$ and extreme potassium enrichment $\left(\mathrm{K}_{2} \mathrm{O} / \mathrm{Na}_{2} \mathrm{O}>3.9\right)$ may represent island arc rocks similar to shoshonites. However, the $\mathrm{K}_{2} \mathrm{O} / \mathrm{Na}_{2} \mathrm{O}$ ratios are much higher than those reported for shoshonites from modern or ancient arcs and may be the result of metamorphism. Samples with moderate $\mathrm{TiO}_{2}(1.4$ to $1.5 \mathrm{wt} \%)$ and $\mathrm{Zr}$ (72 to $\left.85 \mathrm{ppm}\right)$ are similar to rocks from mid-ocean ridges. A few samples have $\mathrm{TiO}_{2}$ and $\mathrm{Zr}$ intermediate between island arc and mid-ocean ridge basalt-like rocks. Two samples have high iron $\left(\mathrm{Fe}_{2} \mathrm{O}_{3}{ }^{*}=>12.8\right.$ to $\left.18.5 \mathrm{wt} \%\right)\left(\mathrm{Fe}_{2} \mathrm{O}_{3}{ }^{*}=\right.$ total iron calculated as $\left.\mathrm{Fe}_{2} \mathrm{O}_{3}\right)$ and $\mathrm{TiO}_{2}(>2.3$ wt $\%)$ and resemble FeTi basalt recovered from mid-ocean ridges. Metamorphism in most samples ranges from low-temperature zeolite, typical of ocean floor weathering, to prehnite-pumpellyite facies and perhaps lower greenschist. Blue amphibole and lawsonite minerals are present in several samples. One diabase clast (Sample 9) exhibits $\mathrm{Ca}$ enrichment, similar to rodingite metamorphism, typical of mafic blocks in serpentinized masses. The presence of both low-grade (clays and zeolites) and higher grade (lawsonite) metamorphism indicates retrograde processes in these clasts.

These clasts are fragments of the forearc crust and possibly of the subducting plate that have been entrained in the rising serpentine and may represent the deepest mafic rocks ever recovered from the Mariana forearc. The variable compositions and degree of metamorphism of these clasts requires at least two tectonic origins. The recovery of clasts with mid-ocean ridge and arc chemical affinities in a single drill hole requires these clasts to have been "mixed" on a small scale either (1) in the forearc crustal sequence, or (2) after inclusion in the rising serpentine mud. The source of the MORB-like samples and an explanation for the presence of both MORB-like and arc-like rocks in close proximity is critical to any model of the evolution of the Mariana forearc. The source of the MORB-like samples likely will be one (or more) of the following: (1) accretion of Pacific plate lithosphere, (2) remnants of original forearc crust (trapped plate), (3) volcanism in the supra-subduction zone (arc or forearc) environment, or (4) derivation from the subducting slab by faulting along the décollement.
\end{abstract}

\section{INTRODUCTION}

\section{Objectives of Leg 125}

Approximately one-half of the time devoted to Ocean Drilling Program (ODP) Leg 125 was spent drilling at four sites on a serpentine seamount in the outer Mariana forearc (Conical Seamount, $19^{\circ} 30^{\prime} \mathrm{N}, 146^{\circ} 40^{\prime} \mathrm{E}$ ) (Fig. 1). One of the two primary objectives of the leg was to drill through the flanks of the seamount into underlying basement to investigate the origin and evolution of forearc terranes. Igneous forearc crust recovered in the vicinity of the serpentine seamounts can provide a comparison with the $340 \mathrm{~m}$ of igneous crust recovered during Deep Sea Drilling Project (DSDP) Leg 60 (Hussong, Uyeda, et al., 1981).

Two sites are located on the southern flank (Sites 778 and 779) and one at the summit (Site 780) of the seamount (Fig. 1). The fourth site (Site 781) is located just northwest of the topographic expression of the serpentine seamount and is discussed by Marlow et al. (this volume). This paper discusses the mafic clasts recovered in Holes $778 \mathrm{~A}$ and $779 \mathrm{~A}$ and their importance in understanding intraoceanic forearc development.

As expected from previous studies (Bloomer and Hawkins, 1983; Fryer et al., 1985, 1990a; Fryer and Fryer, 1987; Saboda et al., 1987; Saboda, 1991), sheared serpentine muds and homogeneous serpentinized harzburgite are the primary rock types that were recovered

'Fryer, P., Pearce, J. A., Stokking, L. B., et al., 1992. Proc. ODP, Sci. Results, 125: College Station, TX (Ocean Drilling Program).

${ }^{2}$ University of Hawaii, School of Ocean and Earth Science and Technology, 2525 Correa Rd., Honolulu, HI 96822, U.S.A. (Present address: Naval Research Laboratory, Code 5110, Washington, DC 20375-5000, U.S.A.) from the seamount sites $(778,779$, and 780$)$ (Fryer, Pearce, Stokking, et al., 1990) (Fig. 1). Hole 780A at the summit of Conical Seamount (Fig. 1) was drilled to a depth of 163.5 meters below seafloor (mbsf) and encountered serpentine muds with rare blocks of serpentinized ultramafic rock; no mafic rocks were recovered. Drilling on the flanks of the seamount at Holes 778A and 779A (Fig. 1) reached 107.6 and 317.2 mbsf, respectively. Although drilling ceased at Sites 778 and 779 , before reaching in-situ basement beneath the seamount, sparse fragments of mafic igneous rock are intimately intermixed with the serpentine mud and serpentinized ultramafic rock (Fryer, Pearce, Stokking, et al., 1990). The mafic rocks are present primarily as small (4-8 cm), fine-grained, rounded clasts of metabasalt; however, one large interval $(392 \mathrm{~cm})$ of coarser grained, possibly intrusive, rock was cored at Hole 779A. The sparse volume of these mafic clasts suggests that they are present as "xenoliths" in the serpentine seamounts. The drilling results indicate that the seamount is a large mud volcano venting deep seated fluids (Mottl et al., this volume) and erupting serpentine muds and entrained clasts from depth through a central conduit (Fryer et al., this volume). Metamorphic minerals in most of these clasts are typical of the prehnite-pumpellyite to greenschist facies; however, in some of these clasts minerals typical of the blueshist facies are present (Maekawa et al., this volume), suggesting they may have been plucked from deep within the forearc. The Torishima Forearc Seamount, a serpentine seamount drilled in the Izu-Bonin forearc at $31^{\circ} \mathrm{N}$ (Sites 783 and 784), yielded only a few small clasts of mafic rock.

Although mafic fragments from Conical Seamount represent less than $9 \%$ of the total rock recovered (in drill holes), the great chemical diversity and the wide range in metamorphic grade suggests that they may represent fragments of forearc crust as well as fragments of the 


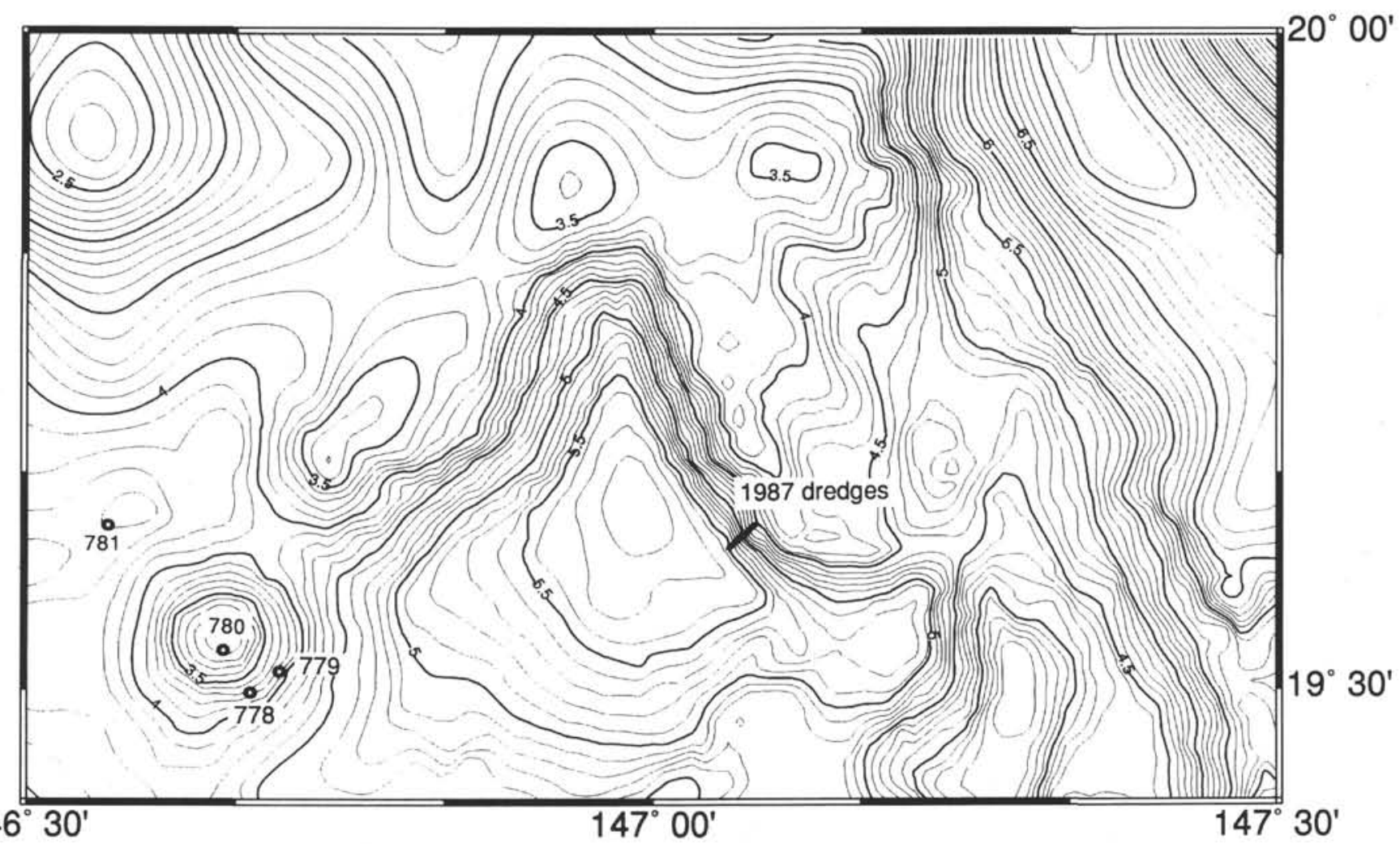

Figure 1. Bathymetric map showing the Serpentine Seamount drilled during Leg 125 and a steep scarp in the outer Mariana forearc. Filled circles are locations for samples discussed, open circles are other drill sites, line represents dredge tracks of Johnson and Fryer (1990a). Contours are in kilometers.

subducting plate. The presence of these rocks has significant implications for the formation and evolution of the Mariana forearc and may help broaden our understanding of the tectonic processes that control the composition, structure, and development of intraoceanic forearc regions.

\section{Tectonic Setting and Description of Serpentine Seamounts}

A large number of seamounts (up to $2000 \mathrm{~m}$ high) lie in the outer Mariana forearc, 60 to $100 \mathrm{~km}$ from the trench axis. Previous investigations (including dredging, diving, and side-scan sonar studies) show that Conical Seamount (Fig. 1) consists primarily of variably serpentinized ultramafic rock and serpentine muds (Hussong and Fryer, 1985; Fryer et al., 1987, 1990a). Earlier investigators proposed that serpentine bodies are formed when fluids from the subducting Pacific Plate, released by compaction and dehydration reactions, become incorporated into the overlying mantle wedge (Bloomer, 1983; Fryer and Fryer, 1987). Formation of serpentine mud volcanoes probably results from serpentinization of forearc mantle by interaction with this fluid, causing a decrease in density and allowing ascent of serpentinized mantle along fractures in the forearc. Serpentine mud carrying large, often rounded, blocks of ultramafic rock erupts from a central conduit and forms a large edifice, probably within a period of 1.5 to 2 m.y. (Fryer et al., 1990a). Blocks observed during Alvin dives range in size from 0.5 to $2 \mathrm{~m}$ in diameter and blocks up to $4 \mathrm{~m}$ were drilled. Smaller fragments of mafic rock, such as those found in Holes $778 \mathrm{~A}$ and $779 \mathrm{~A}$, may be brought to the seafloor together with the serpentine, although none have yet been identified in dredge hauls from Conical Seamount.

\section{Previous Studies of Mafic Rocks in the Mariana Forearc}

Previous drilling in the Mariana forearc during DSDP Leg 60 recovered a total of $340 \mathrm{~m}$ of igneous basement at two forearc sites (Sites 448 and 449). All of the igneous rock recovered (Mattey et al., 1980; Meijer et al., 1981; Wood et al., 1981; Sharaskin, 1981) can be grouped into the single chemical-tectonic affinity of the island-arc tholeiite series of Hickey and Frey (1982) that includes boninites and island-arc tholeiitic basalts (IAT). Dredges from the inner trench wall recovered mafic igneous rocks almost solely of IAT affinity (Bloomer and Hawkins, 1983, 1987; Bloomer, 1983). A small amount of alkalic basalt recovered in three dredges from the inner trench wall is an exception and probably represents local accretion of seamount fragments (Bloomer and Hawkins, 1983). A more recent study of rocks dredged from a steep scarp in the outer forearc $(\sim 60 \mathrm{~km}$ from the trench axis and $40 \mathrm{~km}$ northeast of the Leg 125 drill sites) (Johnson et al., 1987; Johnson and Fryer, 1990a) did, however, discover a very diverse suite of rocks, including metabasalts with geochemical signatures indicative of rocks formed in four different tectonic environments: (1) oceanic spreading centers that create mid-ocean ridge basalt (MORB); (2) intraplate hotspots that create oceanic island basalt (OIB); and supra-subduction zone (SSZ) margins that create (3) IAT and (4) forearc igneous rocks such as boninites or forearc rift related lavas. Cretaceous cherts recovered with these rocks are consistent with accretion of Pacific Plate crust (Johnson et al., 1991).

Despite petrologic and compositional overlap, there is a difference in the style of occurrence of the mafic samples between Sites 778 and 779. Mafic rocks account for approximately $9 \%$ of total recovery from Hole $778 \mathrm{~A}$ and are present in six of 13 cores taken. These samples, as well as the sparse clasts from Holes 783A and 784A, are present 
as isolated, rounded fragments of brecciated metabasalt, 2 to $8 \mathrm{~cm}$ in diameter, that ordinarily lie in direct contact with serpentine clay. Compositionally and petrographically distinct clasts are found adjacent to one another and do not appear to be part of continuous blocks. In contrast, Hole 779A mafic rocks, approximately $7 \%$ of the total recovery, are present in only three intervals within 37 cores recovered. Hole $779 \mathrm{~A}$ mafic clasts are larger, constituting a 62 - and a 390-cm section of core for each of a single rock type (Samples 11 and 9, respectively). One exception is a single, isolated, rounded clast of cumulate gabbro at the bottom of the hole (Core 125-779A-36R, Sample 1). The different manner of occurrence of clasts between the two holes (the small, scattered fragments for Hole 778A compared with the large blocks for Hole 779A) may be related to the source area of the serpentine flows that carried these clasts or, perhaps, to variable internal structure of the seamount itself.

\section{PETROGRAPHY AND GEOCHEMISTRY: MAFIC IGNEOUS CLASTS}

\section{Analytical Procedures}

Thin sections of 36 samples were prepared, and 18 whole-rock analyses were made from 11 of the meta-mafic samples that were of sufficient size for analyses (Table 1). Major and trace element analyses by X-ray fluorescence (XRF) were performed both aboard the JOIDES Resolution and at the University of Hawaii (UH) (Table 2). Rare earth element (REE) analyses of seven clasts were performed at Lamont-Doherty Geological Observatory (LDGO) by directly coupled plasma (DCP) spectrometry (Table 3). Techniques for the shipboard analyses are described in Fryer, Pearce, Stokking, et al. (1990); those for UH and LDGO are described below. Samples numbered 1 through 11 are those which have been analyzed (Table 2). Standard ODP sample designations are given in Table 1.

Powders were prepared from rocks washed in distilled water, chipped to pieces less than $0.5 \mathrm{~cm}$ in size, and rewashed in distilled water, in an ultrasonic cleaner, three to six times or until the water remained unclouded. Cleaned rock chips were then powdered in an alumina mill.

Whole-rock analyses at UH were performed using an automated Siemens XRF. Fused glass disks (major elements) and pressed powder pellets (trace elements) were prepared and online data reduction accomplished using the methods of Norrish and Hutton (1969) and Norrish and Chappell (1977). Glass disks were prepared from rock powders ignited at $950^{\circ}$ to drive off volatiles, mixed with a lithium meta-borate flux, and fused at $1000^{\circ} \mathrm{C}$. Volatiles are listed in Table 2 as loss on ignition (LOI). Pressed pellets were prepared from $\sim 5 \mathrm{~g}$ of rock powder, mixed with a polyvinyl alcohol binder, and pressed into a boric acid casing. An error was noted in $\mathrm{Na}_{2} \mathrm{O}$ values for samples analyzed aboard the JOIDES Resolution, causing them to be systematically low. $\mathrm{Na}_{2} \mathrm{O}$ values have been corrected for all samples in Table 2 either by new analyses (noted in Table 2) or by using an empirical correction factor. See Arculus et al. (this volume) for a complete discussion.

REE analyses at LDGO were performed on rock powders ignited at $950^{\circ} \mathrm{C}$, mixed with an ultra-pure lithium meta-borate (MatheyJohnston, Puratronic) flux, fused in a graphite crucible at $1060^{\circ} \mathrm{C}$, and dissolved in $1 \mathrm{~N} \mathrm{HCl}$. This solution was filtered to remove graphite particles and washed onto cation exchange columns (filled with 200-400-mesh analytical grade resin) with ultra-pure water for REE separation. REE-concentrated samples were dried overnight in teflon beakers, redissolved in a $1 \mathrm{~N} \mathrm{HNO}_{3}$ solution spiked with $\mathrm{K}, \mathrm{P}$, and $\mathrm{Be}$, and analyzed by DCP spectrometry. The P and Be were used as internal standards to correct for short-term drift, while $\mathrm{K}$ acted as a signal enhancer. Distilled reagent grade acids diluted with ultra-pure water were used for all phases of REE analyses. Data reduction included blank subtraction, correction for long- and short-term drift, and known elemental interferences. Absolute abundances were determined by comparison to two basaltic standards (K1919 and All-9229 ), and precision was determined from repeat analyses of several samples as unknowns. The precision for repeat analyses of a mid-Atlantic ridge basalt is listed in Table 3 and has $<2 \%$ standard deviation ([1 s.d./average value $\times 100$ ) for all elements. Because of a random, sporadic La contamination problem, the La values for all samples are suspect and have been included only where independent or duplicate information is available.

\section{Petrography}

The mafic igneous clasts, though sparse in number and volume, are diverse in rock type. This diversity precludes any attempt to place these samples in geochemical groups (Table 1).

Of the 34 thin sections of mafic rock examined (Table 1), 24 are metabasalts and 10 are metadiabases. One is a boninite (Sample 125-778 A-8R-1, 18-20 cm) and one is a breccia (Sample 125-778A$7 \mathrm{R}-1,1-2 \mathrm{~cm}$ ) of mixed boninite and basalt clasts. Because of the high degree of metamorphism, the diverse assemblage of clasts, and the lack of a clear petrographic grouping, only a brief summary of the petrography is given here (Table 1). Detailed descriptions for most samples are given in Fryer, Pearce, Stokking, et al. (1990). Metabasalts at Holes 778 A and 779 A are typically aphyric and fine-grained (Table 1). Some preserve a sparsely intersertal to intergranular texture of plagioclase needles and equant clinopyroxene microphenocrysts in a glassy to very fine-grained holocrystalline matrix. Metamorphic textures are discussed below.

The metadiabase (Sample 9, Table 1) occurs in Hole 779A (Cores 125-779A-31R to -32R) and comprises a continuous 390-cm segment (recovered length) of variably crystallized metabasalt to diabase. The degree of crystallization increases from glassy to aphyric and finegrained at the top to subophitic and medium- to coarse-grained toward the center of the block, suggesting that it is a single cooling unit. The original rock had a modal composition of $20 \%$ to $40 \%$ clinopyroxene and $10 \%$ to $45 \%$ plagioclase and a weakly intersertal texture. This unit is overlain by serpentinized ultramafic rocks and serpentine mud and overlies a fragmented mixture of serpentinized dunite and metabasalt/diabase similar in composition to Sample 9.

A single sample with classic boninitic textures (Sample 125$778 \mathrm{~A}-8 \mathrm{R}-1,18-20 \mathrm{~cm}$ ) is fine-grained with $10 \%$ microphenocrysts of orthopyroxene. The brecciated sample (Sample 125-778A-7R-1, $\mathrm{I}-2 \mathrm{~cm}$ ) consists of $0.5-$ to $1.5-\mathrm{cm}$ clasts of boninite and metabasalt similar to those already described in a matrix of detrital metamorphosed mafic rock.

\section{Secondary Textures and Metamorphism}

Most samples, especially the isolated clasts from Site 778, have developed secondary sheared or brecciated textures. Extensive chlorite, carbonate, and prehnite-pumpellyite veining commonly overprint primary igneous textures. All samples exhibit low-temperature, possibly sub-seafloor metamorphism that is characterized by the replacement of glassy and fine-grained matrix by amorphous clay and chlorite. However, in some clasts this low-temperature metamorphism appears to be retrograde following higher pressure metamorphism such as that described by Maekawa et al. (this volume). Zeolites and epidote are present in some samples (Table 1). Much of the plagioclase has been albitized, and chlorite and fibrous hornblende commonly replace pyroxene. Relict crystals of clinopyroxene are present in most samples, but relict plagioclase is rare. Lawsonite and sparse blue amphibole are present in some clasts (Maekawa et al., this volume). Sample 9 (Table 1) has undergone pervasive metamorphism in the prehnite-pumpellyite facies.

Sample 9 exhibits the extreme Ca-enrichment (up to $25 \%$ ) and the complete loss of alkalis $(\mathrm{K}, \mathrm{Na}$, and $\mathrm{Rb}$ ) characteristic of rodingite metamorphism (Coleman, 1967). Metamorphism is pervasive; no relict plagioclase remains and only sparse, skeletal remnants of clinopyroxene remain. Rodingite metamorphism is a common phenomenon in ophiolite exposures-for instance, New Zealand(Coleman, 1966) and California 
Table 1. Brief petrographic descriptions of mafic clasts.

\begin{tabular}{|c|c|c|c|c|c|c|c|}
\hline $\begin{array}{l}\text { Core, section, } \\
\text { interval }(\mathrm{cm})\end{array}$ & $\begin{array}{l}\text { Sample } \\
\text { number" }\end{array}$ & $\begin{array}{l}\text { Elements } \\
\text { analyzed }^{b}\end{array}$ & Rock type $^{c}$ & $\mathrm{TiO}_{2}(\%)$ & Texture $^{d}$ & Grain size $e^{e}$ & Other texture \\
\hline \multicolumn{8}{|l|}{$125-778 \mathrm{~A}-$} \\
\hline $4 \mathrm{R}-1,1-2$ & & & Bas & & Aph & & Subophitic, sheared \\
\hline $5 \mathrm{R}-1,7-10$ & 2 & $\mathrm{M}, \mathrm{T}, \mathrm{R}$ & Bas & 0.29 & Aph & & Subophitic \\
\hline $6 \mathrm{R}-1,20-23$ & & & Bas & & Spph & M & Blastic, sheared \\
\hline $7 \mathrm{R}-1,1-2$ & & & Breccia & & & & Intergranular \\
\hline $7 \mathrm{R}-1,2-3$ & & & And & & Spph & M & Sheared \\
\hline $8 \mathrm{R}-1,18-20$ & & & Bon(?) & & Aph & $\mathrm{F}$ & Glassy \\
\hline $9 \mathrm{R}-1,15-18$ & 3 & M. T & Bas & 0.92 & & & \\
\hline 9R-CC, $28-31$ & & & Bas & & Aph & VF & Brecciated \\
\hline 9R-CC, $9-12$ & 4 & M, T, R & Bas & 0.94 & & $\mathrm{~F}$ & Intersertal, veined \\
\hline 10R-CC, $1-3$ & & & Bas & & Aph & M & \\
\hline 10R-CC, $22-24$ & & & Bas & & Spph & $\mathrm{F}$ & Brecciated \\
\hline $11 \mathrm{R}-1,0-3$ & 10 & $\mathrm{M}, \mathrm{T}, \mathrm{R}$ & Bas & 2.32 & & & \\
\hline $11 \mathrm{R}-1,4-7$ & & & Bas & 1.10 & Spph & $\mathrm{M}$ & \\
\hline $11 \mathrm{R}-1,5-7$ & 5 & M. T, R & Bas & 1.12 & & & \\
\hline 11R-CC, 7-9 & & & Bas & & Spph & M & Veined \\
\hline $13 R-1,4-6$ & 6 & M, T & Bas & & & & \\
\hline $13 \mathrm{R}-1,9-12$ & & & Bas & & & & Glassy \\
\hline $13 \mathrm{R}-1,12-14$ & 7 & M, T & Bas & 1.09 & Aph & & \\
\hline $13 \mathrm{R}-\mathrm{CC}, 4-6$ & 8 & M, T, R & Bas & 1.33 & Aph & & Veined \\
\hline \multicolumn{8}{|l|}{$125-779 \mathrm{~A}-$} \\
\hline $9 \mathrm{R}-1,66-68$ & & & Bas & & & F-M & \\
\hline $9 \mathrm{R}-1,97-99$ & & & Bas & & Aph & $\mathrm{F}$ & Veined \\
\hline $9 \mathrm{R}-1,106-108$ & $11 \mathrm{a}$ & $\mathrm{M}, \mathrm{T}, \mathrm{R}$ & Bas & 2.50 & & VF & \\
\hline $9 \mathrm{R}-1,117-119$ & $11 \mathrm{~b}$ & $\mathrm{M}, \mathrm{T}$ & Bas & 2.38 & Aph & $\mathrm{F}$ & Veined \\
\hline $31 \mathrm{R}-1,102-103$ & & & Dia & & $\mathrm{Ph}$ & $\mathrm{F}$ & Quench, veined \\
\hline $31 \mathrm{R}-1,112-115$ & & & Dia & & Aph & $\mathrm{F}$ & Intersertal \\
\hline $31 \mathrm{R}-1,119-121$ & $9 \mathrm{a}$ & M, T & Dia & 1.41 & $\mathrm{Ph}$ & M & Intersertal \\
\hline $31 \mathrm{R}-2,0-4$ & $9 \mathrm{~b}$ & $\mathrm{M}, \mathrm{T}, \mathrm{R}$ & Dia & 1.38 & $\mathrm{Ph}$ & $\mathrm{M}$ & Intergranular \\
\hline $31 \mathrm{R}-2,100-102$ & & & Dia & & $\mathrm{Ph}$ & $\mathrm{M}$ & \\
\hline $31 \mathrm{R}-2,103-105$ & $9 \mathrm{c}$ & $\mathrm{M}, \mathrm{T}, \mathrm{R}$ & Dia & 1.40 & $\mathrm{Ph}$ & $\mathrm{M}$ & Intergranular \\
\hline $31 \mathrm{R}-2,119-122$ & & & Dia & & $\mathrm{Ph}$ & $\mathrm{F}-\mathrm{M}$ & \\
\hline $31 \mathrm{R}-3,32-34$ & 9d & M, T & Dia & 1.26 & $\mathrm{Ph}$ & $\mathrm{M}$ & Intersertal \\
\hline 3IR-CC, $25-27$ & $9 \mathrm{e}$ & $\mathrm{M}, \mathrm{T}, \mathrm{R}$ & Dia & 1.51 & $\mathrm{Ph}$ & c & \\
\hline $31 \mathrm{R}-\mathrm{CC}, 39-41$ & $9 \mathrm{f}$ & M. T & Dia & 1.48 & $\mathrm{Ph}$ & $\mathrm{F}$ & \\
\hline $36 \mathrm{R}-3,0-3$ & 1 & $\mathrm{M}, \mathrm{T}$ & Cum & 0.19 & & & \\
\hline $125-783 \mathrm{~A}-15 \mathrm{R}-2,84-86$ & & & Dia & & Aph & M & Veined \\
\hline $125-784 \mathrm{~A}-39 \mathrm{R}-1,5-6$ & & & Bas & & Aph & & Glassy, veined \\
\hline
\end{tabular}

Note: See Initial Reports volume (Fryer, Pearce, Stokking, et al., 1990) for more detailed descriptions.

${ }^{2}$ Discussed in this paper.

${ }^{\mathrm{b}} \mathrm{M}=$ major, $\mathrm{T}=$ trace, $\mathrm{R}=$ rare earth.

${ }^{\mathrm{C}} \mathrm{Bas}=$ metabasalt, $\mathrm{And}=$ metaandesite, $\mathrm{Dia}=$ metadiabase, $\mathrm{Cum}=$ cumulate, $\mathrm{Bon}=$ boninite

${ }^{\mathrm{A}} \mathrm{Aph}=$ aphyric, $\mathrm{Ph}=$ phyric, $\mathrm{Spph}=$ sparsely phyric.

${ }^{\mathrm{c}} \mathrm{VF}=$ very fine, $\mathrm{F}=$ fine, $\mathrm{M}=$ medium, $\mathrm{C}=$ coarse.
${ }^{\mathrm{ft}} \mathrm{x}$ " indicates presence of mineral. Mineral abbreviations: $\mathrm{Plag}=$ plagioclase, $\mathrm{Cpx}=$ clinopyroxene, $(\mathrm{m})=$ present in groundmass only, Ap $=$ apatite, $\mathrm{Ol}=$ olivine, $\mathrm{Chl}=$ chlorite, $\mathrm{Carb}=$ carbonate, $\mathrm{Pr}-\mathrm{pu}=$ prehnite-pumpellyite association, $\mathrm{Z}=$ zeolite, $\mathrm{Gt}=$ hydrogrossular garnet, $\mathrm{Q}=$ quartz, $\mathrm{Ep}=$ epidote, $\mathrm{Ox}=$ oxide, $\mathrm{Serp}=$ serpentine, $\mathrm{Lw}=$ lawsonite, and $\mathrm{BA}=$ blue amphibole. $\mathrm{Lw}$ and $\mathrm{BA}$ identified by Maekawa et al. (this volume).

and Oregon (Coleman, 1967). Blocks of mafic rock that have intruded into or been tectonically emplaced into ultramafic rocks are metamorphosed simultaneously with serpentinization of the ultramafic rock. The metamorphism of Sample 9 is homogeneous throughout the block, as demonstrated by the REE and incompatible element patterns (Figs. 2 and 3). A particularly interesting observation is that the REEs of Sample 9 form smooth chondrite-normalized patterns consistent with immobile element interpretations of premetamorphic compositions. I conclude that REE are either immobile during rodingite metamorphism or have been mobilized as a coherent group. The extent and homogeneity of rodingitization suggests intrusion or tectonic incorporation of the mafic block into the ultramafic rocks before or during serpentinization and emplacement into the Mariana forearc. However, the higher than normal concentrations of serpentinizing fluids present within Conical Seamount may accelerate the reaction time for rodingitization, thus allowing for emplacement of this block into the serpentine muds after initial serpentinization and seamount formation.

\section{Major and Trace Element Abundances}

The generally high degree of metamorphism of the rocks requires that the geochemical discussion be centered on elements thought to be immobile during most metamorphic processes. Many of these samples have unusual major element abundances, and in some cases these abundances can be explained by the metamorphic process. For example, the high $\mathrm{Ca}$ and lack of alkalis in Sample 9 are characteristic of rodingite metamorphism. Other unusual values, such as the high $\mathrm{MgO}$ for Samples 7 and 8, remain unexplained by either primary igneous processes (i.e., fractionation, crystal accumulation) or ob- 
Table 1 (continued).

\begin{tabular}{|c|c|c|c|c|c|c|c|c|c|c|}
\hline \multirow[b]{2}{*}{$\begin{array}{l}\text { Core, section, } \\
\text { interval }(\mathrm{cm})\end{array}$} & \multicolumn{5}{|c|}{ Original mineralogy ${ }^{f}$} & \multicolumn{5}{|c|}{ Metamorphic minerals ${ }^{f}$} \\
\hline & Plag & $\mathrm{Cpx}$ & Spinel & Glass & Other & $\mathrm{ChI}$ & Clay & Carb & Pr-pu & Other \\
\hline \multicolumn{11}{|l|}{$125-778 \mathrm{~A}-$} \\
\hline $4 \mathrm{R}-1,1-2$ & $\mathrm{x}$ & $\mathrm{x}$ & $\mathrm{x}$ & $\mathrm{x}$ & & $\mathrm{x}$ & $\mathrm{x}$ & & & \\
\hline $5 R-1,7-10$ & $x(m)$ & $\mathrm{x}(\mathrm{m})$ & $\mathrm{x}$ & $\mathrm{x}$ & & $\mathrm{x}$ & & & & \\
\hline $6 \mathrm{R}-1,20-23$ & $x(m)$ & $x(m)$ & $x$ & $\mathrm{x}$ & Ap & $\mathrm{x}$ & $\mathrm{x}$ & & $\mathrm{x}$ & Lw \\
\hline $7 R-1,1-2$ & $x(m)$ & $x(m)$ & $\mathrm{x}$ & $\mathrm{x}$ & & & $\mathrm{x}$ & $\mathrm{x}$ & & Q \\
\hline $7 \mathrm{R}-1,2-3$ & $x(m)$ & $x(m)$ & $\mathrm{x}$ & $\mathrm{x}$ & & $\mathrm{x}$ & $\mathrm{x}$ & & $\mathrm{x}$ & Ep \\
\hline $8 \mathrm{R}-1,18-20$ & (imi) & $\mathrm{x}$ & & $\hat{x}$ & Ol & & $\hat{x}$ & $x$ & & \\
\hline $9 \mathrm{R}-1,15-18$ & & & & & & & & & & \\
\hline 9R-CC, 28-31 & $x(m)$ & $x(m)$ & $x$ & $x$ & & $\mathrm{x}$ & $x$ & & $\mathrm{x}$ & Z, Ep, Ox, Q, Lw \\
\hline 9R-CC, 9-12 & $x$ & $\mathrm{x}$ & $\mathrm{x}$ & $\mathrm{x}$ & & $\mathrm{x}$ & $\mathrm{x}$ & & $\mathrm{x}$ & Talc \\
\hline 10R-CC, $1-3$ & $x(m)$ & $\mathrm{x}(\mathrm{m})$ & $\mathrm{x}$ & & & $\mathrm{x}$ & $\mathrm{x}$ & $\mathrm{x}$ & & $\mathrm{Ox}$ \\
\hline 10R-CC, 22-24 & $\mathrm{x}$ & $\mathrm{x}$ & & & & $\mathrm{x}$ & & $\mathrm{x}$ & $\mathrm{x}$ & Talc, Q, Lw \\
\hline $11 \mathrm{R}-1,0-3$ & & & & & & & & & & \\
\hline $11 \mathrm{R}-1,4-7$ & $\mathrm{x}$ & $\mathrm{x}$ ? & $\mathrm{x}$ & $\mathrm{x}$ & Ol & $x$ & $\mathrm{x}$ & $\mathrm{x}$ & & Q \\
\hline $11 \mathrm{R}-1,5-7$ & & & & & & & & & $\mathrm{x}$ & Lw \\
\hline $11 \mathrm{R}-\mathrm{CC}, 7-9$ & $\mathrm{x}$ & $\mathrm{x}$ & & & Ol & $\mathrm{x}$ & & & & Ox \\
\hline $13 \mathrm{R}-1,4-6$ & $\mathrm{x}$ & $\mathrm{x}$ & $\mathrm{x}$ & $\mathrm{x}$ & & & $\mathrm{x}$ & & & \\
\hline $13 R-1,9-12$ & $\mathrm{x}$ & $\mathrm{x}$ & $\mathrm{x}$ & $\mathrm{x}$ & $\mathrm{x}$ & $\mathrm{x}$ & $\mathrm{x}$ & $\mathrm{x}$ & $\mathrm{x}$ & \\
\hline $13 R-1,12-14$ & $x(m)$ & $x(m)$ & $\mathrm{x}$ & $\mathrm{x}$ & & $\mathrm{x}$ & & & $\mathrm{x}$ & $\mathrm{z}$ \\
\hline 13R-CC, $4-6$ & $x(m)$ & $\mathrm{x}(\mathrm{m})$ & $\mathrm{x}$ & $\mathrm{x}$ & & & $\mathrm{x}$ & & $x$ & Gt, Q, BA \\
\hline \multicolumn{11}{|l|}{$125-779 \mathrm{~A}-$} \\
\hline $9 \mathrm{R}-1,66-68$ & $x$ & $\mathrm{x}$ & & & & & & & & $\mathrm{Z}$ \\
\hline $9 \mathrm{R}-1,97-99$ & & $\mathrm{x}(\mathrm{m})$ & & & & $\mathrm{x}$ & $\mathrm{x}$ & & & $\mathrm{Z}$ \\
\hline $9 R-1,106-108$ & $\mathrm{x}(\mathrm{m})$ & $x(m)$ & $\mathrm{x}$ & & & & & & & $\mathrm{Z}$ \\
\hline $9 \mathrm{R}-1,117-119$ & $\mathrm{x} ?$ & $\mathrm{x}$ & & & & $\mathrm{x}$ & & & & Q \\
\hline $31 \mathrm{R}-1,102-103$ & $x(m)$ & $\mathrm{x}$ & $x$ & $\mathrm{x}$ & & $\mathrm{x}$ & $\mathrm{x}$ & & & Serp \\
\hline $31 \mathrm{R}-1,112-115$ & $\mathrm{x}$ & $\mathrm{x}$ & & & & $\hat{x}$ & $\hat{x}$ & & & \\
\hline $31 \mathrm{R}-1,119-121$ & $\mathrm{x}$ & $\mathrm{x}$ & $\mathrm{x}$ & & & $\mathrm{x}$ & $\mathrm{x}$ & & & \\
\hline $31 \mathrm{R}-2,0-4$ & $x$ & $\mathrm{x}$ & & & & $\mathrm{x}$ & $\mathrm{x}$ & & & \\
\hline $31 \mathrm{R}-2,100-102$ & $\mathrm{x}$ & $\mathrm{x}$ & $\mathrm{x}$ & & & $\mathrm{x}$ & $\mathrm{x}$ & & & Gt \\
\hline $31 \mathrm{R}-2,103-105$ & $\mathrm{x}$ & $\mathrm{x}$ & $\mathrm{x}$ & & & $\mathrm{x}$ & $\mathrm{x}$ & & & Gt \\
\hline $31 \mathrm{R}-2,119-122$ & $\mathrm{x}$ & $\mathrm{x}$ & $\mathrm{x}$ & & & $\mathrm{x}$ & $\mathrm{x}$ & & & Gt \\
\hline $31 \mathrm{R}-3,32-34$ & $\mathrm{x}$ & $\mathrm{x}$ & $\mathrm{x}$ & & & $\mathrm{x}$ & $\mathrm{x}$ & & & \\
\hline $31 \mathrm{R}-\mathrm{CC}, 25-27$ & $\mathrm{x}$ & $\mathrm{x}$ & & & & $\mathrm{x}$ & $\mathrm{x}$ & & & Gt \\
\hline 31R-CC, $39-41$ & $\mathrm{x}$ & $\mathrm{x}$ & & & & $\mathrm{x}$ & $\mathrm{x}$ & & & $\mathrm{Gt}$ \\
\hline $36 \mathrm{R}-3,0-3$ & & $x$ & & & $\mathrm{OI}$ & & & & & \\
\hline $125-783 \mathrm{~A}-15 \mathrm{R}-2,84-86$ & $x(m)$ & $\mathrm{x}(\mathrm{m})$ & & $x$ & & $\mathrm{x}$ & & & & Q, Ep \\
\hline $125-784 \mathrm{~A}-39 \mathrm{R}-1,5-6$ & $x(m)$ & $x(m)$ & $\mathrm{x}$ & $\mathrm{x}$ & & $\mathrm{x}$ & & $\mathrm{x}$ & & Ox \\
\hline
\end{tabular}

servable metamorphic processes (i.e., veining, addition of metamorphic minerals). Major elements $\left(\mathrm{Al}_{2} \mathrm{O}_{3}\right.$; Pearce, 1975), minor elements (Ti, P; Pearce and Cann, 1973), trace elements (V, Cr, Y, Zr, $\mathrm{Nb}$; Shervais, 1982), and the REEs (Ce-Lu; Humphris and Thompson, 1978; Morrison, 1978) have been shown to be immobile during normal seafloor weathering. Samples are numbered with respect to increasing $\mathrm{TiO}_{2}$ concentration (Table 2), and the abundance of immobile incompatible elements (Ti, Zr, Y, and the REE; Fig. 3) generally increases with sample number.

Analyses from several intervals are presented for two of 11 clasts analyzed (Samples 9 and 11; Table 2). On the basis of REE and immobile element patterns (Fig. 2 and 3), and two trace element discrimination diagrams (Fig. 4A-B), these clasts can be identified as (1) SSZ rocks (Samples 1 through 4), (2) depleted MORB-like rocks (Samples 5 through 7), (3) MORB-like rocks (Samples 8 and 9), and (4) high-Fe and -Ti rocks (Samples 10 and 11).

The incompatible trace element characteristics of basaltic rocks can be demonstrated and different samples compared using multi-element plots normalized to N-type MORBs (normal-type MORB) (Pearce, 1983; Sun and McDonough, 1989). In Figure 3, high field strength (HFS) elements (Y, Ti, Zr, and the REES), considered immobile during normal seafloor metamorphism, are plotted with the degree of incompatibility during melting (of a lherzolite source) increasing to the right. Magmas derived from a mantle source similar to a MORB source will show a flat pattern, with deviations from this pattern suggesting (1) a different mantle source, (2) a mantle source modified by the addition or loss of selected elements, or (3) metamorphism of the lavas after eruption. Magmas derived from a convecting mantle wedge that overlies a subducting slab should be similar to those of MORB, though more depleted in the incompatible and HFS elements by the melting event that extracted the MORB. Other factors such as crystal accumulation or extensive crystal fractionation may also affect the MORB-normalized ratios (Fig. 3).

Samples 1 and 2 have very low abundances of incompatible (and immobile) elements (Figs. 3 and 4) such as $\mathrm{TiO}_{2}\left(<\mathrm{O} .3\right.$ wt \%), $\mathrm{P}_{2} \mathrm{O}_{5}$ $(<0.1 \mathrm{wt} \%), \mathrm{Zr}(<31 \mathrm{ppm})$, and $\mathrm{Y}(<9 \mathrm{ppm})$. Sample 1 is a metamorphosed cumulate and has high $\mathrm{Ni}$ and $\mathrm{Cr}$ contents. Sample 2 has an irregular REE pattern at $3 \times$ to $5 \times$ chondrite, with a distinct negative Eu anomaly. It is light REE (LREE: La-Nd) depleted $\left([\mathrm{Ce} / \mathrm{Nb}]_{\mathrm{N}}=\right.$ 0.69 ) and has an unusually heavy REE (HREE: Dy-Lu) enrichment trend (Fig. 2). Sample 2 also has an extreme Ce depletion and a small but distinct $\mathrm{Ti}$ depletion relative to other incompatible elements (normalized to N-MORB) (Fig. 3).

Samples 3 and 4 have low abundances of $\mathrm{TiO}_{2}(0-9 \mathrm{wt} \%), \mathrm{Zr}$ (43-50 ppm) and Y (18-21 ppm) relative to the N-MORB normalizing value (Figs. 3 and 4). An unusual feature of these two samples is 


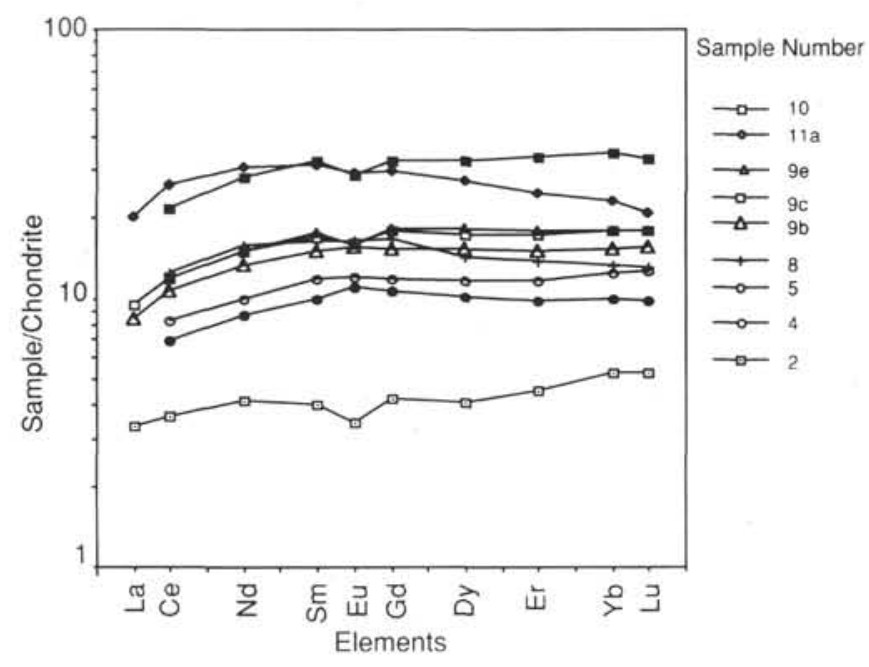

Figure 2. Chondrite-normalized REE patterns. All samples are plotted at the same scale and are identified by sample number. Note the increasing abundances of REE with sample number. Normalization values are given in Table 3.

the high abundance of $\mathrm{K}_{2} \mathrm{O}$ (>3.1 wt\%) and $\mathrm{Rb}$ (57 to $67 \mathrm{ppm}$ ). Sample 4 is slightly LREE depleted $\left([\mathrm{Ce} / \mathrm{Sm}]_{N}=0.70\right)$, has a small positive Eu anomaly, and flat HREE at about $10 \times$ chondrite (Fig. 2). There is a slight but distinct kink in the REE pattern between Gd and Dy, causing the HREE to be slightly depleted with respect to the middle REE ( $\mathrm{Sm}-\mathrm{Gd}$ ). The extreme $\mathrm{K}_{2} \mathrm{O}$ enrichment suggests these rocks may be related to shoshonites that are found in some of the active Mariana island arc volcanoes (Jackson et al., 1987; Bloomer et al., 1989). However, the $\mathrm{K}_{2} \mathrm{O} / \mathrm{Na}_{2} \mathrm{O}$ ratio (>3.9) is unusually high; typical shoshonites have $\mathrm{K}_{2} \mathrm{O} / \mathrm{Na}_{2} \mathrm{O}=0.4-1.2$ (Bloomer et al., 1989). The extremely high $\mathrm{K}_{2} \mathrm{O} / \mathrm{Na}_{2} \mathrm{O}$, and elevated $\mathrm{Rb}$ and $\mathrm{P}$ may be metamorphic effects.

Samples 5, 6, and 7 (Table 2) have abundances of $\mathrm{TiO}_{2}(1.2 \mathrm{wt} \%)$, $\mathrm{Zr}(60 \mathrm{ppm})$, and Y (28 ppm) all slightly higher than Samples 1 through 4 (Figs. 3 and 4). These three samples plot on the border of the IAT and MORB fields of Figure 4A-B. Sample 5 exhibits a smoother REE pattern and is more LREE-depleted $\left([\mathrm{Ce} / \mathrm{Sm}]_{\mathrm{N}}=0.67\right)$ than Samples 2 and 4 (Fig. 2). The N-MORB normalized pattern for Sample 5 is similar to Sample 4 at about $0.8 \times \mathrm{N}-\mathrm{MORB}$, but has a lower value of $P$.

Samples 8 and 9 have similar abundances of many trace elements such as $\mathrm{TiO}_{2}$ (1.4 to $\left.1.5 \mathrm{wt} \%\right), \mathrm{Zr}$ (72 to $85 \mathrm{ppm}$ ), and $\mathrm{Y}$ (29 to $35 \mathrm{ppm}$ ) (Table 2) at about $1 \times \mathrm{N}-\mathrm{MORB}$ (Fig. 3). However, $\mathrm{Ba}, \mathrm{Ni}$, and $\mathrm{Cr}$ are much lower in Sample 8 than in Sample 9. Sample 8 has unusually high $\mathrm{MgO}(23.7 \mathrm{wt} \%)$ that is not caused by an accumulation of mafic phenocrysts (Table 1). Sample 9, represented by six analyses (9a through 9f), has an extremely high abundance of $\mathrm{CaO}$ (19.1 to $24.2 \mathrm{wt} \%$ ); $\mathrm{K}_{2} \mathrm{O}, \mathrm{Na}_{2} \mathrm{O}$, and $\mathrm{Rb}$ are below detection limits for all samples, a feature characteristic of rodingite metamorphism as discussed above. The unusually low abundance Of $\mathrm{SiO}_{2}$ ( 40 to $42 \mathrm{wt} \%$ ) is probably a dilution effect associated with the increased $\mathrm{Ca}$. REE patterns for Samples 8 and 9 are similar at about $10 \times$ to $15 \times$ chondrite. Sample 8 has greater LREE depletion $\left([\mathrm{Ce} / \mathrm{Sm}]_{\mathrm{N}}=0.93\right)$ than Sample $9\left([\mathrm{Ce} / \mathrm{Sm}]_{\mathrm{N}}=0.66-0.69\right)$, and a distinct HREE depletion $\left([\mathrm{Gd} / \mathrm{Lu}]_{\mathrm{N}}=1.25\right)$. Sample 9 exhibits a slight negative Eu anomaly in the two deeper samples ( $9 \mathrm{~b}$ and $9 \mathrm{e}$; Fig. 2), indicating plagioclase fractionation. Samples 8 and 9 plot in the MORB field of Figure 4A-B and are coincident with the field containing the MORB-like rocks of Johnson and Fryer (1990a) (Fig. 4A-B).

Samples 10 and 11 have high contents of $\mathrm{Fe}_{2} \mathrm{O}_{3}$ * (13.6 to $18.5 \mathrm{wt} \%)\left(\mathrm{Fe}_{2} \mathrm{O}_{3} *\right.$ = total iron calculated as $\left.\mathrm{Fe}_{2} \mathrm{O}_{3}\right), \mathrm{Na}_{2} \mathrm{O}$ (3.2 to 4.3 wt $\%), \mathrm{TiO}_{2}(>2.4)$, and $\mathrm{Zr}(>150 \mathrm{ppm})$, characteristics similar to FeTi basalts recovered from mid-ocean ridges (Natland, 1980; Byerly et al., 1976). Sample 10 (Sample 125-778A-1R-1, 0-3 cm) contains the highest iron content and also has a high abundance of $\mathrm{Ni}$ ( $563 \mathrm{ppm})$ and the REEs $(20 x-35 \times$ chondrite). The REE pattern is slightly LREE depleted $\left([\mathrm{Ce} / \mathrm{Sm}]_{\mathrm{N}}=0.66\right)$ and has a small negative Eu anomaly (Fig. 2). Sample 11 (Samples 125-779A-9R-1, 106-108 cm [a], and $117-119 \mathrm{~cm}[\mathrm{~b}])$ has lower contents of $\mathrm{Fe}_{2} \mathrm{O}_{3}$, and $\mathrm{Ni}$ (50 to $52 \mathrm{ppm}$ ), and REE abundances similar to Sample 10 at $20 x-30 \times$ chondrite. However, Sample 11 exhibits a "humped" REE pattern with a middle REE enrichment $\left([\mathrm{Ce} / \mathrm{Sm}]_{N}=1.14 ;(\mathrm{Ce} / \mathrm{Yb})_{\mathrm{N}}=1.06\right)$. Both samples have high $(2 \times-3 \times N-M O R B)$ incompatible element abundances.

\section{Geochemical Interpretations}

A qualitative inspection of the immobile elements of Samples 1 through 4 suggests that these samples are probably not related to the more $\mathrm{TiO}_{2}$-rich samples ( 5 to 11 ) by fractionation of any common mineral phase (plagioclase, pyroxene, olivine) (Fig. 5) or by different degrees of partial melting.

A test for fractionation can be attempted, even with metamorphosed rocks, using plots of immobile but compatible elements such as $\mathrm{Ni}$ (for olivine fractionation) and $\mathrm{Al}_{2} \mathrm{O}_{3}$ (for plagioclase fractionation) vs. an incompatible and immobile element $\left(\mathrm{TiO}_{2}\right)$ (Fig. 5A-B). During fractionation, $\mathrm{TiO}_{2}$ should increase only gradually until the onset of crystallization of a titanium-bearing oxide phase. Thus, if the samples are related by fractionation, plots of $\mathrm{Al}_{2} \mathrm{O}_{3}$ and $\mathrm{Ni}$ vs. $\mathrm{TiO}_{2}$ should show the same trend. However, $\mathrm{TiO}_{2}$ shows no obvious correlation with either $\mathrm{Ni}$ or $\mathrm{Al}_{2} \mathrm{O}_{3}$ (Fig. 5B). Thus, if fractionation is involved it seems likely it is only among samples with similar $\mathrm{TiO}_{2}$, such as Samples 5, 6, and 7.

Ratios of incompatible elements (Figs. 3 and 4, Tables 2 and 3) suggest that these clasts were derived from multiple sources. However, variable degrees of partial melting may also cause variable incompatible element ratios such as those exhibited by $\mathrm{Zr} / \mathrm{Y}$ and $\mathrm{Ce} / \mathrm{Yb}$.

Samples 1 through 4 have very low REE (Fig. 2) and incompatible elements (Fig. 3) and plot in the arc fields of two widely used discrimination diagrams (Figs. 4A-B). The kinked REE (MREE > HREE) pattern for Sample 4 is similar to that for other rocks from the Mariana arc system (Dixon and Stern, 1983). The low abundances of incompatible elements (Fig. 3) is consistent with a depleted source, and formation in a SSZ environment.

The slightly REE-depleted patterns (Fig. 3) and the abundances of the immobile elements (Ti, Z, Y, P, Mn, Cr) (Fig. 4, Table 2) of Samples 8 and 9 are compatible with a mid-ocean ridge or arc-rifting (backarc) origin for these rocks. Samples 5, 6, and 7 are lower than Samples 8 and 9 in abundances of the discriminant elements that may indicate greater extent of partial melt of the same or similar source, or may indicate lower degrees of crystal fractionation. The kink in the REE pattern of Sample 8 may indicate a transitional mantle source or mixing of arc-derived and spreading center-derived magmas and may suggest an arc-rifting origin.

FeTi basalts are thought to form by extreme fractionation of MORB magma. However, the high Ni content of Sample 10 indicates that it is not a fractionated rock, and thus that the high contents of iron and titanium may be a primary characteristic. The ratios of $\mathrm{Ni}$ and $\mathrm{Al}_{2} \mathrm{O}_{3}$ to $\mathrm{TiO}_{2}$ do not support the derivation of Samples 10 and 11 from the other samples by fractionation (Fig. 5). A suite of Fe-gabbros was recovered from DSDP Site 458 (Wood et al., 1981). Site 458 $\mathrm{Fe}$-gabbros have arc-like geochemical signatures $\left(\mathrm{TiO}_{2}<1.2 \mathrm{wt} \%\right)$ and are not similar to mafic clasts from Conical Seamount (Fig. 3).

Some aspects of Figure 3, the Ce depletion of Sample 2, and the Penrichment and depletion of Samples 4 and 5, may be explained by metamorphism. However, $\mathrm{Ce}$ and $\mathrm{P}$ are typically considered immobile elements and these depletions and enrichments may represent source characteristics. Nb depletion, together with $\mathrm{Ti}$ and $\mathrm{Ta}$ depletion, is a characteristic of arc-derived rocks. The $\mathrm{Nb}$ depletion apparent in all samples except two (enriched) and four (flat) is unusual and might also be attributed to metamorphism, although the values are so low 


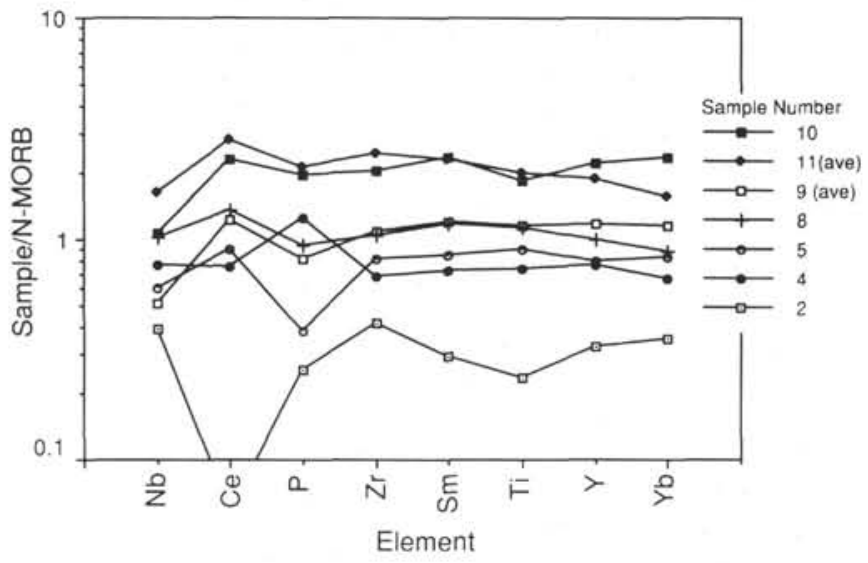

Figure 3. N-MORB normalized incompatible element diagrams. Values plotted are averages for each group and are normalized to the values of Sun and McDonough (1989). Note the increasing HFS-element enrichment with sample number.

that analytical error may be significant; the lack of accompanying $\mathrm{Ti}$ depletion (relative to the other incompatible elements) suggests the $\mathrm{Nb}$ depletion is not a primary characteristic of these samples. Differences in incompatible element abundances can be ascribed to distinct sources and geochemical histories. This is consistent with the lack of any apparent relationship between the samples by crystal fractionation (Fig. 5) or partial melting.

I therefore suggest Samples 1-4 are of SSZ origin and Samples 811 are of mid-ocean ridge origin. The tectonic origin(s) of Samples 57 are ambiguous.

\section{MODELS FOR DEVELOPMENT OF THE MARIANA FOREARC}

Before the discovery of MORB-like rocks in the outer Mariana forearc (Johnson and Fryer, 1990a), models for the formation and evolution of the forearc held that, since inception, the Mariana forearc had been modified primarily by tectonic erosion of the inner trench wall, and SSZ volcanism of IAT and boninite (Bloomer and Hawkins, 1983; Bloomer, 1983; Hawkins et al., 1984). The recovery of MORBlike, OIB, and SSZ rocks mixed on a scale of 2 to $3 \mathrm{~km}$ (Johnson and Fryer, 1990a; Johnson et al., 1991) requires a much more complex model for the formation of the Mariana forearc.

An intrusion of IAT composition was drilled at Site 781 more than $100 \mathrm{~km}$ from the volcanic front, about halfway between the active arc and the trench, (Marlow et al., this volume). Intrusions of arc magma a great distance from the volcanic front, coupled with tectonic emplacement of Pacific oceanic lithosphere, can explain the close juxtaposition of IAT and MORB-like rocks in the outer Mariana forearc. However, volcanism with a MORB-like chemical character also occurs during arc rifting in backarc basins (i.e., Fryer et al., 1981) and arcs (Hochstaedter et al., 1990; Fryer et al., 1990b). During rifting events, this magma type may become injected into or tectonically incorporated into the forearc region. Either intrusion or tectonic incorporation of these rocks may explain the close association of arc and MORB-like rocks, but these scenarios are unable to explain the presence of alkalic (OIB) rocks. The product of forearc rifting is most likely to be of island-arc composition (Taylor, Fujioka, et al., 1990); in-situ MORB-like rocks have never been documented from intraoceanic forearcs. However, the possibility exists that some of these clasts with MORB-like compositions, especially Sample 9, may be the result of a sub-forearc melting event. This is supported by the presumed intrusive nature of the diabase into the serpentine. Neartrench magmatic intrusions in ocean-continent forearcs have been documented from the Paul Revere Ridge near the triple junction of the American-Pacific-Juan de Fuca plates (MacLeod and Pratt, 1973), from the Franciscan Complex of California (Echeverria, 1980), and from southern Chile (Forsythe et al., 1986). The Franciscan Complex and Paul Revere Ridge intrusions both contain tholeiitic rocks that plot in the MORB-IAT overlap field of the $\mathrm{Ti}-\mathrm{Zr}$ discrimination diagram (Pearce and Cann, 1973). Echeverria (1980) suggests that the Ortigalita gabbro of the Franciscan Complex was intruded within $10 \mathrm{~km}$ of the trench axis and resulted from decompression melting of the subducting plate caused by plate flexure seaward of the trench during subduction. The silicic intrusions of southern Chile are approximately $15-20 \mathrm{~km}$ from the trench axis (Forsythe et al., 1986), it is unclear how far from the trench the Paul Revere Ridge samples are intruded (MacLeod and Pratt, 1973). In contrast, Conical Seamount is about $100 \mathrm{~km}$ from the trench. Thus, if the lava of Sample 9 was intruded into the serpentinized rocks of the seamount, it was likely a sub-forearc, not Pacific Plate, melting event. A sub-forearc melting event might be driven by pressure release caused by slab bending as the slab approaches the arc and is perhaps aided by the influx of fluids from the downgoing plate. It is unclear whether such a melting event might produce lavas of a MORB composition. If mantle above the subducting slab and beneath the forearc is convecting (Kushiro, 1990) and a source of fluids is present, sufficiently hot, less-depleted (than typical IAT source) mantle might be able to melt and produce a MORB-like magma. If such melting events occur, the diabase intrusion (Sample 9) may be an example; however, the cold nature of the serpentinite body and the presence of a cold slab beneath the forearc limit the heat available for such melting.

On the basis of the suite of mafic clasts recovered in Holes 778 A and 779A and on the results of dredging (i.e., Bloomer, 1983; Johnson and Fryer, 1990a), it seems likely that there are four possible mechanisms for emplacement of oceanic (MORB-like) rocks into the Mariana forearc.

1. Accretion of fragments of the downgoing oceanic plate into the outer forearc has been documented by Johnson et al. (1991) (Fig. 6A). Such accretion appears to be episodic and may alternate with tectonic erosion of the inner trench wall and toe of the overriding plate. However, accreted fragments would have to be thrust over the outer forearc high and faulted into the pathway of the rising serpentine mud to be entrained in Conical Seamount.

2. The crustal complex in the forearc may contain fragments of oceanic plate that have remained trapped since the inception of this subduction zone and have been incorporated into a largely IAT crustal structure as xenolithic blocks (Fig. 6A). Seismic evidence for such blocks, at $18^{\circ} \mathrm{N}$, exists as a low-velocity layer in refraction surveys (Ambos, 1984) and as a strong reflector in reflection surveys (Mrozowski et al., 1981). Such blocks might supply clasts to the rising serpentine diapir. On the basis of ages of foraminifers and radiolarians (Cretaceous, $>90 \mathrm{Ma}$ ) and the maximum age estimated for the crust of the West Philippine Basin (<56 Ma, Hilde and Lee, 1984), accreted rocks described by Johnson et al. (1991) do not appear to be trapped lithosphere. No ages are available for the metamorphic clasts described in this work.

3. Following arc rifting, pieces of MORB-like, rift-related crust may become part of the forearc. This would occur if the new arc is built farther away (west) from the trench than the previous arc or backarc crust. This crust may be exposed in the outer forearc by erosion at the inner trench wall. A sill of island-arc composition has been described over $100 \mathrm{~km}$ from the arc (Marlow et al., this volume), thus it is possible that intrusions of MORB-like lava, produced during arc rifting, may also be emplaced in the forearc. Sub-forearc melting, caused by the influx of fluids into the overlying mantle (Fig. 6B) and/or decompres- 

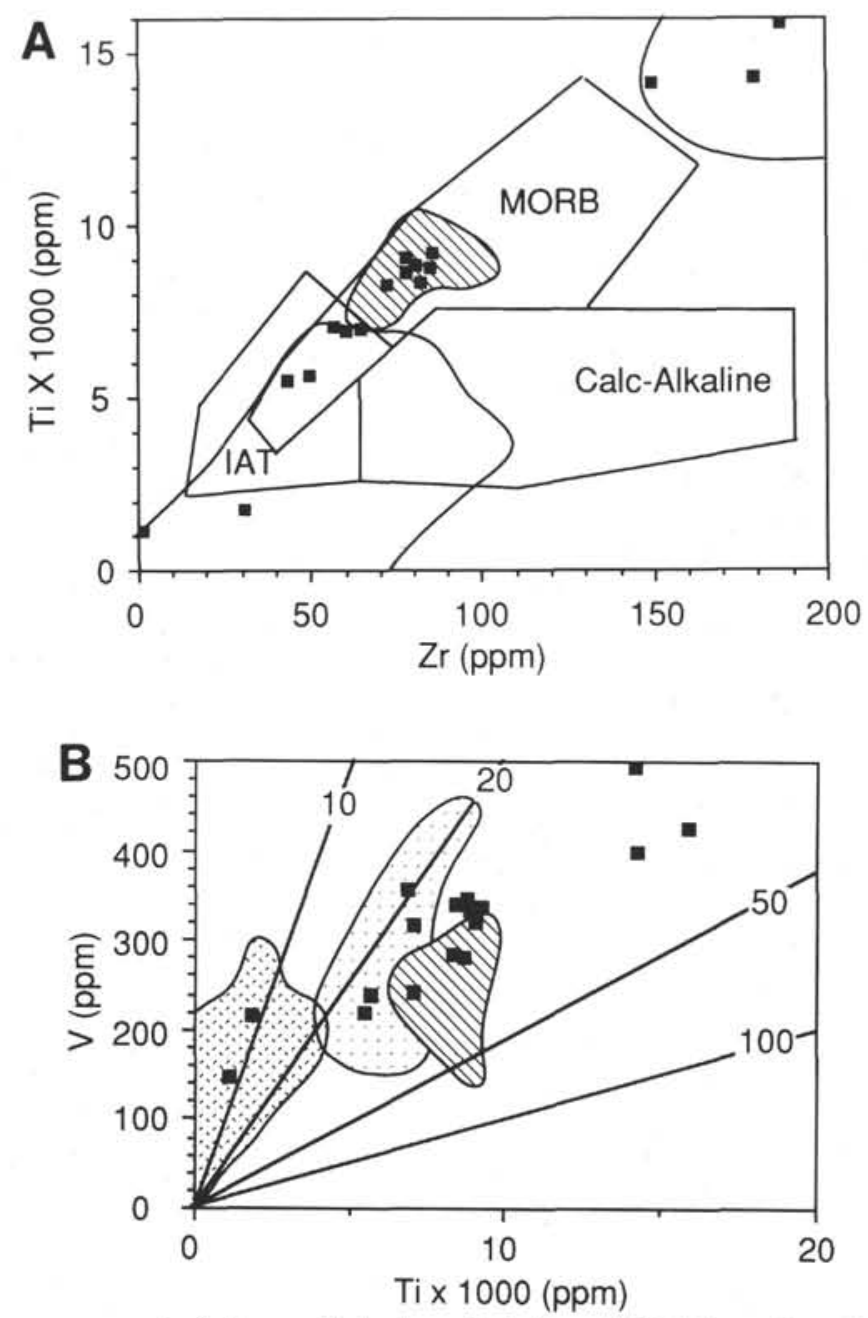

boninites and island arc tholeiites of DSDP Leg 60 and Bloomer (1983) and Bloomer and Hawkins (1983) $\square$ island arc tholeiites of Johnson and Fryer, (1990) MORB-like rocks of Johnson and Fryer, (1990)

Figure 4. Immobile trace element covariation diagrams to fingerprint tectonic environment of magma genesis. A. Ti- $\mathrm{Zr}$ diagram from Pearce and Cann (1973). B. Ti-V diagram from Shervais (1982). Plotted symbols represent samples discussed in this paper. Fields are for previously published Mariana forearc data (Wood et al., 1981; Meijer et al., 1981; Bloomer, 1983; Bloomer and Hawkins, 1987; Johnson and Fryer, 1990a). Lined field is for MORB group of Johnson and Fryer (1990a).

sion melting associated with bending of the subducting plate, may generate magma of MORB-like chemical composition. However, we have no direct evidence for such sub-forearc melting.

4. Fragments from the subducting slab may be underplated to the forearc by extensive faulting along and through the décollement (Fig. $6 \mathrm{C})$. These rocks are then brought into the forearc with the rising serpentine, perhaps aided by vertical tectonic processes. The presence of blue amphibole and lawsonite in some of the mafic clasts (Table 1; Maekawa et al., this volume) supports a deep origin. In order for any of the four mechanisms described above to produce the geochemically diverse forearc sampled at Conical Seamount and at scarp exposures, rocks with MORB-like and OIB compositions must first be emplaced in the forearc. Once such rocks are present, tectonic mixing on a $2-3 \mathrm{~km}$ scale, perhaps accomplished through faulting parallel and normal to the trench, uplift, and intrusions of IAT and
MORB(?), is required to juxtapose MORB-like, OIB, and IAT rocks. Erosion of the inner trench wall would allow rocks originally present or formed nearer the volcanic front to reside in the outer forearc, where they may have become exposed by extensive faulting or brought to the surface by serpentine diapirism. Tectonic erosion has been proposed as a significant factor in the evolution of the Mariana (Hussong and Uyeda, 1981; Bloomer and Hawkins, 1983), the Tonga (Ballance et al., 1989), and the Japan subduction margins (von Huene et al., 1980). Bloomer (1983) estimates at least $50 \mathrm{~km}$ of erosion of the inner trench wall of the Mariana forearc since the initiation of subduction (45 Ma). However, erosion rates as high as $50 \mathrm{~km} / \mathrm{m} . \mathrm{y}^{-1}$ have been estimated for the inner trench wall of the Tonga forearc (Ballance et al., 1989). Accretion in the Mariana forearc has also been proposed on the basis of seismic data (Karig and Ranken, 1983) and is documented by paleontological data (Johnson et al., 1991). Extensive faulting would be required to allow accreted fragments to remain in the forearc once an erosional episode had begun.

\section{CONCLUSIONS: IMPORTANCE OF MAFIC CLASTS}

The varied composition of the mafic clasts in the Mariana forearc provides direct evidence for the igneous composition of the forearc crust and indirect evidence of the tectonic processes that formed and continue to modify the forearc.

Samples 1 through 4 may have been derived from a mantle source that had been previously melted, perhaps at a mid-ocean ridge. This is a characteristic of many SSZ magmas and suggests these clasts represent pieces of subduction-related forearc crust. The high $\mathrm{K}_{2} \mathrm{O} / \mathrm{Na}_{2} \mathrm{O}$ ratio of Samples 3 and 4 may also be indicative of a SSZ environment. The less-depleted (relative to N-MORB) Samples 5 through 9 appear to have been derived from a less-depleted (in HFS elements) mantle than Samples 1 through 4 . Samples 5 through 9 are similar to N-MORBs and may (1) have been derived from the subducting plate, (2) represent pieces of normal oceanic plate crust trapped in the forearc, (3) be the result of rifting within the SSZ environment, or (4) be the result of a sub-forearc melting event. Samples 10 and 11 are similar to FeTi basalts that have been recovered from the mid-ocean ridges and are similar to samples from the Galapagos spreading center (Byerly et al., 1976) and the East Pacific Rise (Natland, 1980), suggesting that they may be pieces of the downgoing plate or remnants of the original oceanic plate trapped in the forearc at the start of subduction.

The studies of these clasts support three main conclusions.

1. The great diversity of the mafic clasts proves that the forearc basement has a varied geochemical composition. Suites of diverse rocks (MORB-like, alkalic, IAT), dredged from a steep scarp in the outer forearc approximately $40 \mathrm{~km}$ northeast of the drill sites (Johnson and Fryer, 1990a) and from another scarp more than $170 \mathrm{~km}$ to the south (at $17^{\circ} 50^{\prime} \mathrm{N}$ ) (Johnson and Fryer, 1990b) are similar to the clasts recovered in these drill holes, extending the area of the Mariana forearc where rocks having oceanic affinity have been recovered to at least $7000 \mathrm{~km}^{2}$. This is in direct conflict with earlier models (i.e., Hussong and Uyeda, 1981; Bloomer, 1983; Bloomer and Hawkins, 1983) that suggest the forearc formed chiefly by intrusions of arc magmas and tectonic erosion at the inner trench wall. The suite of igneous rocks recovered from Holes 778 A and 779A geochemically resembles samples dredged from fault scamps, some of which have been shown to be contain tectonically accreted rocks. The recovery of widespread MORB-like rocks in the forearc requires a new model for forearc evolution.

2. The clasts are entrained in the rising serpentine muds, and therefore may have been plucked from forearc basement. The presence of lawsonite and blue amphibole (Maekawa et al., this volume) proves that samples may have been derived from depths greater than those drilled during Leg 125 (317 mbsf) or during Leg 60 (692 mbsf) (Hussong et al., 1981) and greater than those dredged 


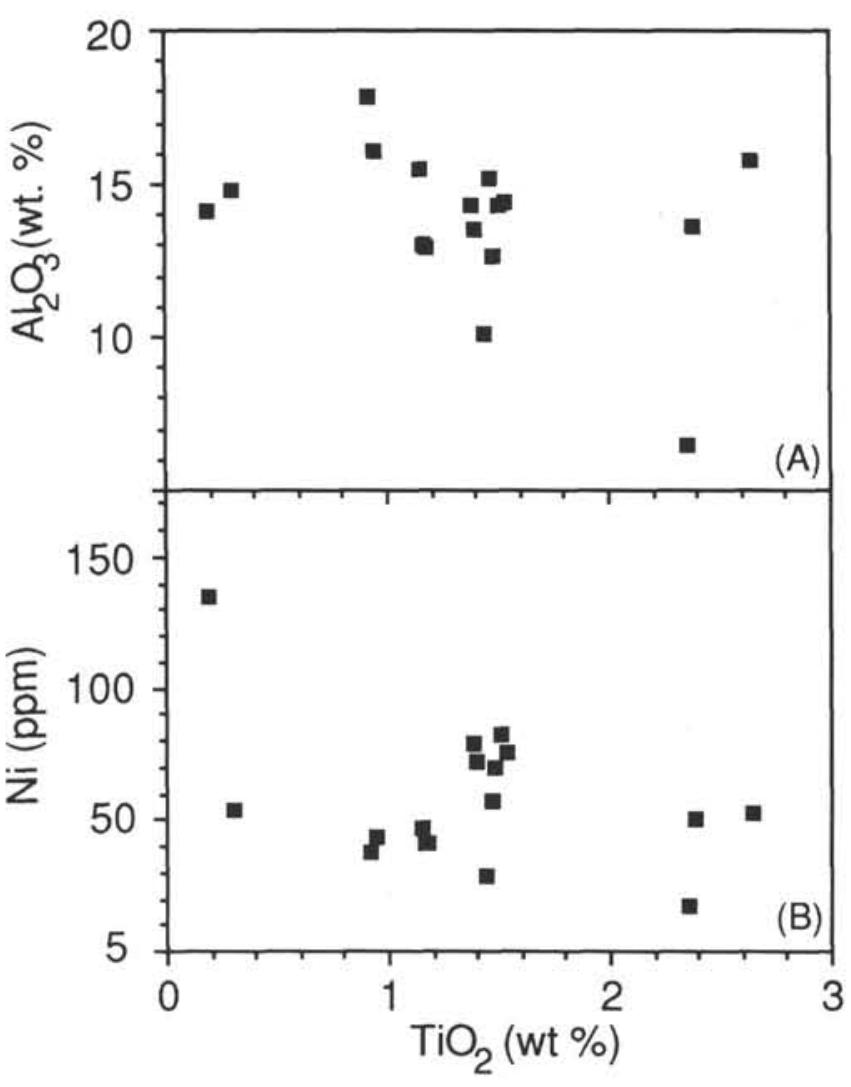

Figure 5. Variation plots to demonstrate the lack of fractional crystallization control by olivine $\left(\mathrm{Ni}\right.$ vs. $\left.\mathrm{TiO}_{2}\right)$ and plagioclase $\left(\mathrm{Al}_{2} \mathrm{O}_{3}\right.$ vs. $\left.\mathrm{TiO}_{2}\right)$.

(5600 m total depth) (Bloomer, 1983; Johnson and Fryer, 1990a). Serpentine mud volcanoes, such as Conical Seamount, provide an opportunity to look deeper into the forearc than previously possible and thus sample forearc crust unavailable through other methods. If some of these clasts are derived from the downgoing slab, this provides an opportunity to study in detail the effects of subduction upon the oceanic crust.

3. The rodingite metamorphism of Sample 9 (Core 125-779A$31 \mathrm{R}$ ) indicates intrusion or tectonic emplacement of the mafic block into the ultramafic rock before or during serpentinization of the host rock. This clast may have been (1) derived from the downgoing plate and later tectonically included in the rising serpentine diapirs, or (2) intruded into the ultramafic rock or serpentine mud during a forearc magmatic event, or (3) present in the mantle that was metamorphosed to form Conical Seamount.

These conclusions support a new model for the formation of the Mariana forearc. In this model, the forearc is composed of rocks created and emplaced in a SSZ setting and of fragments of the subducting plate. The fragments of the downgoing plate may be incorporated into the lower crust and outer forearc by faulting along the décollement or by faulting (thrusting) over the break in slope of the inner trench wall (Fig. 6A). Although this has not been documented, the possibility that rifting within the forearc might create volcanism with MORB-like characteristics cannot be ruled out. Unfortunately, it is not currently possible to distinguish metamorphosed rocks of MORB-like character that have been formed in or near an arc (backarc basin, arc/forearc rifting) from those formed at a true mid-ocean ridge. Continuing intrusions of arc-derived magma into this oceanic/island arc mixture, such as the Pleistocene sill drilled at Site 781 (Marlow et al., this volume), may provide sufficient vol- canism of IAT character throughout at least the inner forearc to create a mixed crustal sequence. I prefer a scenario where the MORB-like fragments recovered from Holes 778 A and 779 A are emplaced either by accretion into the outer forearc or are trapped remnants of oceanic plate; subsequent lateral faulting and vertical uplift then acted to mix these fragments with preexisting pieces of arc crust. However, the sill-like nature of Sample 9 argues for a sub-forearc emplacement of hot magma directly into or onto the serpentine mud.

The crust of the Mariana forearc is petrologically and tectonically complex. Regardless of the source of the MORB-like lavas, a multistage history and continuing magmatic and tectonic events are required to account for the current petrologic composition of the Mariana forearc.

\section{ACKNOWLEDGMENTS}

I thank the captain, crew, and technicians (especially D. Sims and J. Glasser) of the JOIDES Resolution for their capable assistance during Leg 125. I thank T. Hulsebosch for assisting with XRF and microprobe analyses at the University of Hawaii, and G. Eberhardt, C. Langmuir, and J. Reynolds for their patient assistance during REE analyses at Lamont-Doherty Geological Observatory. P. Fryer, M. O. Garcia, and J. M. Sinton are acknowledged for helpful discussions during the preparation of this paper, and P. Fryer, P. A. Floyd, J. A. Pearce, and J. Shervais for detailed reviews of this manuscript. I gratefully acknowledge USSAC for salary support during Leg 125 and for a post-cruise grant that made this research possible (TAMU Research Foundation P.O. Nos. 20265 and 20352). This research is part of the author's doctoral dissertation at the University of Hawaii and was partially supported by an NSF grant to P. Fryer, OCE 84-11717. This is SOEST contribution no. 2739.

\section{REFERENCES}

Ambos, E. L., 1984. Applications of ocean bottom seismometer data to the study of forearc and transform fault systems [Ph.D. dissert.]. Univ. of Hawaii.

Ballance, P. F., Scholl, D. W., Vallier, T. L., Stevenson, A. J., Ryan, H., Quinterno, P., Blome, C., Barron, J. A., Bukry, D., Cawood, P. A., Chaproniere, G.C.H., Herzer, R. H., and Tappin, D. R., 1989. Subduction of a late cretaceous seamount of the Louisville ridge at the Tonga trenchaccretion, arc fragmentation and accelerated subduction erosion. Tectonics, 8:953-962.

Bloomer, S. H., 1983. Distribution and origin of igneous rocks from the landward slopes of the Mariana Trench: implications for its structure and evolution. J. Geophys. Res., 88:7411-7428.

Bloomer, S. H., and Hawkins, J. W., 1983. Gabbroic and ultramafic rocks from the Mariana trench: an island arc ophiolite. In Hayes, D. E. (Ed.), The Tectonic and Geologic Evolution of Southeast Asian Seas and Islands (Pt. 2). Am. Geophys. Union, AGU Monogr. Ser., 27:294-317.

1987. Petrology and geochemistry of boninite series volcanic rocks from the Mariana trench. Contrib. Mineral. Petrol., 97:361-377.

Bloomer, S. H., Stern, R. J., Fish, E., and Geschwind, C. H., 1989. Shoshonitic volcanism in the northern Mariana Arc, 1. Mineralogic and major and trace element characteristics. J. Geophys. Res., 94:4469-4496.

Byerly, G. R., Melson, W. G., and Vogt, P. R., 1976. Rhyodacites, andesites, ferro-basalts and ocean tholeiites from the Galapagos spreading center. Earth. Planet Sci. Lett., 30:215-221.

Coleman, R. G., 1966. New Zealand Serpentinites and Associated Metasomatic Rocks. N.Z. Geol. Surv. Bull. n.s., 76.

, 1967. Low-Temperature Reaction Zones and Alpine Ultramafic Rocks of California. U.S. Geol. Surv. Bull., 1247.

Dixon, T. H., and Stern, R. J., 1983. Petrology, chemistry, and isotopic compositions of submarine volcanoes in the southern Mariana arc. Geol. Soc. Am. Bull., 94:1159-1172.

Echeverria, L. M., 1980. Oceanic basaltic magmas in accretionary prisms: the Franciscan intrusive gabbro. Am. J. Sci., 280:697-724.

Forsythe, R. D., Nelson, E. P., Carr, M. J., Kaeding, M. E., Herve, M., Mpodozis, C., Soma, J. M., and Harambour, S., 1986. Pliocene neartrench magmatism in southern Chile: a possible manifestation of ridge collision. Geology, 14:23-27. 

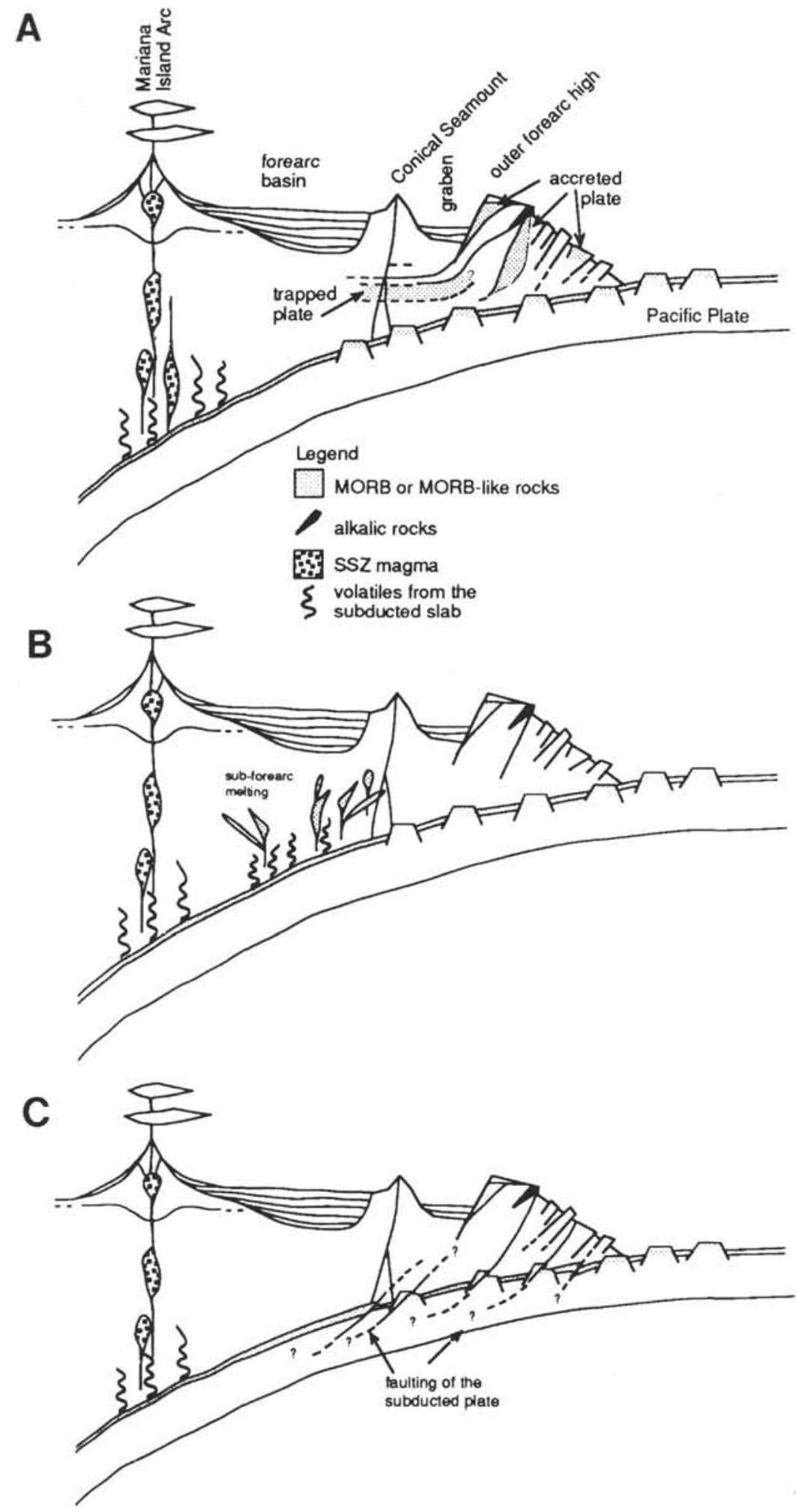

Figure 6. Schematic diagram of the four methods to emplace clasts with MORB-like compositions in the forearc. A. Clasts may be derived from fragments accreted to the outer forearc. The outer forearc high is shown here as a complex block with fragments of rock of MORB, alkalic, and SSZ origins. This has been documented by Johnson et al. (1991). Trapped fragments of the original oceanic plate assumed to have formed the initial forearc might also provide a source of MORB-like clasts. B. If a sub-forearc melting event were to occur, it is possible that it would have a MORB-like composition. This is shown here as true fluid-driven melting in the forearc. However, decompression melting caused by a fractured subducting slab is also possible. C. The outer forearc is extensively faulted; such faulting may be deep enough to intersect the décollement. Faulting along or through the décollement may move fragments of the subducted plate into the path of the rising serpentine mud. 
Table 2. XRF major and trace element data for mafic clasts from Holes 778A and 779A.

\begin{tabular}{lcccccccccccccc}
\hline Sample number & 1 & 2 & 3 & 4 & 5 & 6 & 7 & 8 & $9 \mathrm{a}$ & $9 \mathrm{~b}$ & $9 \mathrm{c}$ & $9 \mathrm{~d}$ & $9 \mathrm{e}$ & $9 \mathrm{f}$ \\
Hole & $779 \mathrm{~A}$ & $778 \mathrm{~A}$ & $778 \mathrm{~A}$ & $778 \mathrm{~A}$ & $778 \mathrm{~A}$ & $778 \mathrm{~A}$ & $778 \mathrm{~A}$ & $778 \mathrm{~A}$ & $779 \mathrm{~A}$ & $779 \mathrm{~A}$ & $779 \mathrm{~A}$ & $779 \mathrm{~A}$ & $779 \mathrm{~A}$ & $779 \mathrm{~A}$ \\
Core, section & $36 \mathrm{R}-3$ & $5 \mathrm{R}-1$ & $9 \mathrm{R}-1$ & $9 \mathrm{R}-\mathrm{CC}$ & $11 \mathrm{R}-1$ & $13 \mathrm{R}-1$ & $13 \mathrm{R}-1$ & $13 \mathrm{R}-\mathrm{CC}$ & $31 \mathrm{R}-1$ & $31 \mathrm{R}-2$ & $31 \mathrm{R}-2$ & $31 \mathrm{R}-3$ & $31 \mathrm{R}-\mathrm{CC}$ & $31 \mathrm{R}-\mathrm{CC}$ \\
Interval $(\mathrm{cm})$ & $0-6$ & $7-10$ & $15-18$ & $9-12$ & $5-8$ & $5-8$ & $12-14$ & $4-6$ & $119-121$ & $0-4$ & $103-105$ & $32-34$ & $25-27$ & $39-41$ \\
\hline
\end{tabular}

Oxides (\%)

\begin{tabular}{|c|c|c|c|c|c|c|c|c|c|c|c|c|c|c|}
\hline $\mathrm{SiO}_{2}$ & 46.24 & 57.70 & 49.58 & 48.02 & 47.94 & 44.53 & 43.17 & 44.28 & 41.34 & 42.27 & 39.92 & 40.89 & 41.68 & 44.06 \\
\hline $\mathrm{TiO}_{2}$ & 0.19 & 0.30 & 0.92 & 0.94 & 1.15 & 1.17 & 1.18 & 1.44 & 1.48 & 1.38 & 1.46 & 1.40 & 1.51 & 1.54 \\
\hline $\mathrm{Al}_{2} \mathrm{O}_{3}$ & 14.07 & 14.81 & 17.88 & 16.05 & 15.49 & 13.06 & 12.93 & 10.07 & 12.64 & 14.33 & 15.20 & 13.51 & 14.35 & 14.38 \\
\hline $\mathrm{Fe}_{2} \mathrm{O}_{3}$ & 4.40 & 8.45 & 8.22 & 8.73 & 13.37 & 12.52 & 11.44 & 10.86 & 11.56 & 10.55 & 12.46 & 11.47 & 11.98 & 13.25 \\
\hline $\mathrm{MnO}$ & 0.17 & 0.17 & 0.17 & 0.18 & 0.18 & 0.27 & 0.25 & 0.24 & 0.22 & 0.19 & 0.19 & 0.19 & 0.22 & 0.19 \\
\hline $\mathrm{MgO}$ & 19.70 & 7.80 & 7.03 & 7.92 & 2.63 & 7.04 & 18.27 & 23.69 & 11.97 & 7.29 & 7.81 & 7.00 & 7.99 & 7.89 \\
\hline $\mathrm{CaO}$ & 15.70 & 3.11 & 11.88 & 12.71 & 9.62 & 18.19 & 10.89 & 6.72 & 19.10 & 24.16 & 22.61 & 23.88 & 22.67 & 21.96 \\
\hline $\mathrm{Na}_{2} \mathrm{O}$ & n.d. & 6.16 & 0.97 & 0.92 & 6.14 & 1.82 & 0.83 & 1.14 & n.d. & n.d. & n.d. & n.d. & n.d. & n.d. \\
\hline $\mathrm{K}_{2} \mathrm{O}$ & 0.10 & 0.16 & 3.79 & 3.14 & 0.83 & 0.31 & 0.83 & 0.02 & n.d. & n.d. & n.d. & n.d. & n.d. & n.d. \\
\hline $\mathrm{P}_{2} \mathrm{O}_{5}$ & n.d. & 0.03 & 0.06 & 0.14 & 0.05 & 0.08 & 0.09 & 0.11 & 0.09 & 0.11 & 0.08 & 0.09 & 0.11 & 0.09 \\
\hline Total & 100.55 & 97.81 & 100.48 & 98.58 & 96.51 & 98.67 & 99.22 & 98.36 & 98.38 & 100.27 & 99.70 & 98.42 & 100.50 & 99.38 \\
\hline LOI & 6.94 & 2.91 & 6.10 & 3.78 & 3.95 & 4.45 & 7.30 & 7.94 & 4.47 & 4.33 & 4.02 & 9.76 & 4.62 & 3.96 \\
\hline
\end{tabular}

Trace elements (ppm)

$\begin{array}{lrrr}\mathrm{Nb} & \text { n.d. } & 1.5 & 1.8 \\ \mathrm{Zr} & 1.6 & 31.0 & 43.4 \\ \mathrm{Y} & 4.0 & 9.1 & 17.5 \\ \mathrm{Sr} & 48.5 & 50.9 & 66.0 \\ \mathrm{Rb} & 2.6 & 2.9 & 66.7 \\ \mathrm{Zn} & 20.5 & 55.5 & 63.8 \\ \mathrm{Cu} & 19.1 & 298.8 & 35.0 \\ \mathrm{Ni} & 135.5 & 53.9 & 38.1 \\ \mathrm{Cr} & 660.7 & 85.0 & 119.7 \\ \mathrm{~V} & 146.0 & 215.3 & 219.0 \\ \mathrm{Ce} & \text { n.a. } & 5.9 & \text { n.a. } \\ \mathrm{Ba} & 29.9 & 2.3 & 43.3 \\ \mathrm{U} & 2.0 & \text { n.a. } & 2.1 \\ \mathrm{Sc} & 42.8 & \text { n.a. } & 26.8 \\ \mathrm{Co} & 39.0 & \text { n.a. } & 47.8 \\ \mathrm{Zr} / \mathrm{Y} & 0.41 & 3.41 & 2.47 \\ \mathrm{Ti} & 1109 & 1768 & 5485\end{array}$

$\begin{array}{rrrr}1.8 & 1.4 & 1.2 & 5.0 \\ 50.1 & 60.3 & 64.3 & 57.0 \\ 21.3 & 22.4 & 28.4 & 28.0 \\ 94.8 & 61.6 & 95.4 & 82.3 \\ 57.1 & 16.3 & 6.1 & 16.7 \\ 70.7 & 100.3 & 92.2 & 94.7 \\ 35.4 & 205.7 & 75.4 & 51.2 \\ 44.0 & 46.7 & 41.6 & 41.1 \\ 116.5 & 68.3 & 150.5 & 170.0 \\ 239.2 & 357.2 & 316.8 & 242.4 \\ \text { n.d. } & \text { n.d. } & 16.2 & 10.3 \\ 53.6 & 46.3 & 57.8 & 33.0 \\ \text { n.a. } & \text { n.a. } & \text { n.a. } & \text { n.a. } \\ \text { n.a. } & \text { n.a. } & \text { n.a. } & \text { n.a. } \\ \text { n.a. } & \text { n.a. } & \text { n.a. } & \text { n.a. } \\ 2.35 & 2.69 & 2.26 & 2.04 \\ 5640 & 6863 & 7013 & 7073\end{array}$

$$
\begin{array}{r}
2.4 \\
77.6 \\
28.1 \\
43.6 \\
\text { n.d. } \\
73.5 \\
49.1 \\
28.4 \\
42.6 \\
280.9 \\
8.3 \\
14.2 \\
\text { n.a. } \\
\text { n.a. } \\
\text { n.a. } \\
2.76 \\
8631
\end{array}
$$

$\begin{array}{rr}0.5 & 2.1 \\ 81.0 & 72.3 \\ 33.8 & 28.9 \\ 62.0 & 58.1 \\ \text { n.d. } & \text { n.d. } \\ 92.8 & 74.6 \\ 55.6 & 56.0 \\ 69.3 & 79.2 \\ 207.2 & 268.2 \\ 333.6 & 284.5 \\ 6.8 & \text { n.a. } \\ 32.5 & 45.2 \\ \text { n.a. } & 2.8 \\ \text { n.a. } & 35.3 \\ \text { n.a. } & 59.4 \\ 2.40 & 2.51 \\ 8841 & 8272\end{array}$

$\begin{array}{rr}1.1 & 1.2 \\ 84.6 & 82.2 \\ 35.2 & 33.7 \\ 92.3 & 49.0 \\ \text { n.d. } & \text { n.d. } \\ 93.6 & 104.0 \\ 48.6 & 38.0 \\ 56.9 & 71.6 \\ 129.6 & 195.9 \\ 345.2 & 339.2 \\ 9.8 & \text { n.d. } \\ 59.1 & 31.6 \\ \text { n.a. } & \text { n.a. } \\ \text { n.a. } & \text { n.a. } \\ \text { n.a. } & \text { n.a. } \\ 2.40 & 2.44 \\ 8721 & 8392\end{array}$

$\begin{array}{rr}2.0 & 0.2 \\ 78.0 & 85.3 \\ 31.1 & 35.4 \\ 58.1 & 57.5 \\ \text { n.d. } & \text { n.d. } \\ 96.0 & 99.2 \\ 60.4 & 55.1 \\ 82.9 & 75.0 \\ 235.6 & 218.8 \\ 320.8 & 337.2 \\ \text { n.a. } & 14.7 \\ 45.4 & 50.4 \\ 3.1 & \text { n.a. } \\ 42.1 & \text { n.a. } \\ 63.5 & \text { n.a. } \\ 2.51 & 2.41 \\ 9051 & 9231\end{array}$

analysis

b

b

a $\quad$ a $\quad$ a $\quad a^{*}$

a

a

Notes: Samples are numbered in order of increasing $\mathrm{TiO}_{2}$. Samples $9 \mathrm{a}-9 \mathrm{e}$ and $11 \mathrm{a}-11 \mathrm{~b}$ are each from a single clast. Abbreviations: n.d. $=$ none detected; n.a. $=$ not analyzed; LOI $=$ loss on ignition.

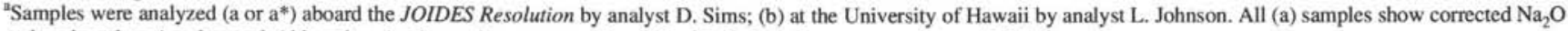
values based on Arculus et al. (this volume); $\mathrm{a}^{*}$ samples were reanalyzed for $\mathrm{Na}_{2} \mathrm{O}$ (J. A. Pearce, pers. comm., 1991).

Fryer, P., Ambos, E. L., and Hussong, D. M., 1985. Origin and emplacement of Mariana forearc seamounts. Geology, 13:774-777.

Fryer, P., and Fryer, G. J., 1987. Origins of nonvolcanic seamounts in a forearc environment. In Keating, B., Fryer, P., and Batiza, R. (Eds.), Seamounts, Islands, and Atolls. Am. Geophys. Union, AGU Monogr. Ser., 43:61-69.

Fryer, P., Haggerty, J. A., Tilbrook, B., Sedwick, P., Johnson, L. E., Saboda, K. L., Newsom, S. Y., Karig, D. E., Uyeda, S., and Ishii, T., 1987. Results of studies of Mariana forearc serpentinite diapirism. Eos, 68:1534.

Fryer, P., Pearce, J. A., Stokking, L. B., et al., 1990. Proc. ODP, Init. Repts., 125: College Station, TX (Ocean Drilling Program).

Fryer, P., Saboda, K. L., Johnson, L. E., Mackay, M. E., Moore, G. F., and Stoffers, P., 1990a. Conical seamount: SeaMARC II, Alvin submersible, and seismic reflection studies. In Fryer, P., Pearce, J. A., Stokking, L. B., et al., Proc. ODP, Init. Repts., 125: College Station, TX (Ocean Drilling Program), 69-80.

Fryer, P., Sinton, J., and Philpotts, J., 1981. Basaltic glasses from the Mariana Trough. In Hussong, D. M., and Uyeda, S., et al., Init. Repts. DSDP, 60: Washington (U.S. Govt. Printing Office), 601-610.

Fryer, P., Taylor, B., Langmuir, C. H., and Hochstaedter, A. G., $1990 \mathrm{~b}$. Petrology and geochemistry of lavas from the Sumisu and Torishima backarc rifts. Earth Planet. Sci. Lett., 100:161-178.

Hawkins, J. W., Bloomer, S. H., Evans, C. A., and Melchior, J. T., 1984. Evolution of intra-oceanic arc-trench systems. Tectonophysics, 102:175-205.

Hickey, R. L., and Frey, F. A., 1982. Geochemical characteristics of boninite series volcanics: implications for their source. Geochim. Cosmochim. Acta, 46:2099-2115.

Hilde, T.W.C., and Lee, C. S., 1984. Origin and evolution of the west Philippine basin: a new interpretation. Tectonophysics, 102:85-104.
Hochstaedter, A. G., Gill, J. B., Kusakabe, M., Newman, S., Pringle, M. Taylor, B., and Fryer, P., 1990. Volcanism in the Sumisu rift. I. Major element, volatile and stable isotope geochemistry. Earth Planet. Sci. Lett., 100:179-194.

Humphris, S. E., and Thompson, G., 1978. Hydrothermal alteration of oceanic basalts by seawater. Geochim. Cosmochim. Acta, 42:107-125.

Hussong, D. M., and Fryer, P., 1985. Fore-arc tectonics in the northern Mariana Arc. In Nasu, N., Kobayashi, K., Uyeda, S., et al., (Eds.), Formation of Active Ocean Margins: Tokyo (Terra Sci. Publ.), 273-290.

Hussong, D. M., and Uyeda, S., 1982. Tectonic processes and the history of the Mariana Arc: a synthesis of the results of Deep Sea Drilling Project Leg 60. In Hussong, D. M., Uyeda, S., et al., Init. Repts. DSDP, 60: Washington (U.S. Govt. Printing Office), 909-929.

Hussong, D. M., Uyeda, S., et al., 1981. Init. Repts. DSDP, 60: Washington (U.S. Govt. Printing Office).

Jackson, M. C., Fryer, P., and Gill, J. B., 1987. Petrology of volcanic rocks collected on a recent Alvin cruise to the Kasuga Volcanoes, northern Mariana Arc. Eos, 68:1532.

Johnson, L. E., and Fryer, P., 1990a. The first evidence of MORB-like lavas from the outer Mariana forearc: geochemistry, petrography and tectonic implications. Earth Planet. Sci. Lett., 100:304-316.

Johnson, L. E., and Fryer, P., 1990b. Mariana forearc mafic crustal complex: a preemplacement analogue to the Coast Range Ophiolite, CA. Eos, $71: 1648$.

Johnson, L. E., Fryer, P., and Ishii, T., 1987. Mariana forearc basement adjacent to serpentinite diapirs. Eos, 1534.

Johnson, L. E., Fryer, P., Taylor, B., Silk, M., Sliter, W. V., Jones, D. L., Itaya, T., and Ishii, T., 1991. New evidence for crustal accretion in the outer 


\section{E. JOHNSON}

Table 2 (continued).

\begin{tabular}{lrrr}
\hline Sample number & \multicolumn{1}{c}{10} & \multicolumn{1}{c}{$11 \mathrm{a}$} & \multicolumn{1}{c}{$11 \mathrm{~b}$} \\
Hole & $778 \mathrm{~A}$ & $779 \mathrm{~A}$ & $779 \mathrm{~A}$ \\
Core, section & $11 \mathrm{R}-1$ & $\begin{array}{c}9 \mathrm{R}-1 \\
9 \mathrm{R}-1\end{array}$ \\
Interval $(\mathrm{cm})$ & $0-3$ & $106-108$ & $117-119$ \\
\hline Oxides $(\%)$ & & & \\
& & & \\
$\mathrm{SiO}_{2}$ & & & \\
$\mathrm{TiO}_{2}$ & 45.98 & 45.98 & 46.51 \\
$\mathrm{Al}_{2} \mathrm{O}_{3}$ & 2.36 & 2.65 & 2.38 \\
$\mathrm{Fe}_{2} \mathrm{O}_{3}$ & 6.51 & 15.79 & 13.62 \\
$\mathrm{MnO}_{\mathrm{MgO}}$ & 18.53 & 12.78 & 13.73 \\
$\mathrm{CaO}$ & 0.26 & 0.16 & 0.19 \\
$\mathrm{Na}_{2} \mathrm{O}$ & 11.93 & 8.08 & 7.90 \\
$\mathrm{~K}_{2} \mathrm{O}$ & 9.43 & 7.77 & 12.41 \\
$\mathrm{P}_{2} \mathrm{O}_{5}$ & 4.14 & 5.38 & 3.18 \\
& 0.03 & 0.55 & 0.28 \\
$\mathrm{Total}_{\mathrm{LOI}}$ & 0.23 & 0.23 & 0.27 \\
& & & \\
& 98.78 & 98.26 & 100.44 \\
& 1.74 & 5.44 & 5.79
\end{tabular}

Trace elements (ppm)

\begin{tabular}{|c|c|c|c|}
\hline $\mathrm{Nb}$ & 2.5 & 2.6 & 5.0 \\
\hline $\mathrm{Zr}$ & 149.7 & 186.9 & 178.9 \\
\hline $\mathrm{Y}$ & 62.0 & 47.7 & 56.8 \\
\hline $\mathrm{Sr}$ & 40.9 & 168.7 & 163.4 \\
\hline $\mathrm{Rb}$ & n.d. & 9.9 & 5.0 \\
\hline $\mathrm{Zn}$ & 93.1 & 131.6 & 124.4 \\
\hline $\mathrm{Cu}$ & 56.9 & 50.7 & 45.5 \\
\hline $\mathrm{Ni}$ & 563.1 & 52.1 & 50.2 \\
\hline $\mathrm{Cr}$ & 109.1 & 163.3 & 126.7 \\
\hline V & 494.3 & 424.1 & 397.3 \\
\hline $\mathrm{Ce}$ & 11.2 & 22.5 & n.a. \\
\hline $\mathrm{Ba}$ & 24.8 & 26.7 & 25.9 \\
\hline $\mathrm{U}$ & n.a. & n.a. & 1.6 \\
\hline $\mathrm{Sc}$ & n.a. & n.a. & 40.2 \\
\hline Co & n.a. & n.a. & 54.1 \\
\hline $\mathrm{Zr} / \mathrm{Y}$ & 2.41 & 3.92 & 3.15 \\
\hline $\mathrm{Ti}$ & 14146 & 15854 & 14236 \\
\hline analysis & a & $a^{*}$ & \\
\hline
\end{tabular}

Mariana forearc: Cretaceous radiolarian cherts and MORB-like lavas. Geology, 19:811-814.

Karig, D. E., and Ranken, D., 1983. Marine geology of the forearc region, southern Mariana island arc. In Hayes, D. E. (Ed.), The Tectonic and Geologic Evolution of Southeast Asian Seas and Islands (Pt. 2). Am. Geophys. Union, AGU Monogr. Ser., 23:266-280.

Kushiro, I., 1990. Partial melting of mantle wedge and evolution of island arc crust. Geophys. Res., 95;15929-15939.

MacLeod, N. S., and Pratt, R. M., 1973. Petrology of volcanic rocks recovered on Leg 18. In Kulm, L. D., von Huene, R., et al., Init. Repts. DSDP, 18: Washington (U.S. Govt. Printing Office), 935-945.

Mattey, D. P., Marsh, N. G., and Tarney, J., 1980. The geochemistry, mineralogy, and petrology of basalts from the West Philippine and Parece Vela basins and from the Palau-Kyushu and West Mariana ridges, Deep Sea Drilling Project Leg 59. In Kroenke, L., and Scott, R., et al., Init. Repts. DSDP, 59: Washington (U.S. Govt. Printing Office), 753-796.
Meijer, A., Anthony, E., and Reagan, M., 1982. Petrology of volcanic rocks from the forearc sites. In Hussong, D. M., and Uyeda, S., Init. Repts. DSDP, 60: Washington (U.S. Govt. Printing Office), 709-729.

Morrison, M. A., 1978. The use of "Immobile" trace elements to distinguish the palaeotectonic affinities of metabasalt: applications to the Paleocene basalts of Mull and Skye, Northwest Scotland. Earth Planet. Sci. Lett., 39:407-416.

Mrozowski, C. L., Hayes, D. E., and Taylor, B., 1981. Multichannel seismic reflection surveys of Leg 60 sites, Deep Sea Drilling Project. In Hussong, D., Uyeda, S., et al., Init. Repts. DSDP, 60: Washington (U.S. Govt. Printing Office), 57-69.

Natland, J. H., 1980. Effect of axial magma chambers beneath spreading centers on the compositions of basaltic rocks. In Rosendahl, B. R., Hekinian, R., et al., Init. Repts. DSDP, Washington (U.S. Govt. Printing Office), 833-850.

Norrish, K., and Chappell, B., 1977. X-Ray fluorescence spectrometry. In Zussman, J. (Eds.), Physical Methods in Determinative Minerals: New York (Academic Press), $201-272$.

Norrish, K., and Hutton, J. T., 1969. An accurate X-ray spectrographic method for the analysis of a wide range of geological samples. Geochim. Cosmochim. Acta, 33:431-453.

Pearce, J. A., 1975. Basalt geochemistry used to investigate past tectonic environments on Cyprus. Tectonophysics, 25:41-67.

Pearce, J. A., 1983. The role of sub-continental lithosphere in magma genesis at destructive plate margins. In Hawkesworth, C. J., and Norry, M. J. (Eds.), Continental Basalts and Mantle Xenoliths: Nantwich (Shiva), 230-250.

Pearce, J. A., and Cann, J. R., 1973. Tectonic setting of basic volcanic rocks determined using trace element analyses. Earth Planet. Sci. Lett., 19:290-300.

Saboda, K. L., 1991. Petrology of ultramafic rocks from Conical Seamount based on Alvin submersible and Ocean Drilling Project studies [M.S. thesis]. Univ. of Hawaii.

Saboda, K. L., Fryer, P., and Fryer, G. J., 1987. Preliminary studies of metamorphic rocks collected during Alvin studies of Mariana forearc seamounts. Eos, 68:1534.

Sharaskin, A. Y., 1982. Petrography and geochemistry of basement rocks from five Leg 60 Sites. In Hussong, D. M., Uyeda, S., et al., Init. Repts. DSDP, 60: Washington (U.S. Govt. Printing Office), 647-656.

Shervais, J. W., 1982. Ti-V plots and the petrogenesis of modern and ophiolitic lavas. Earth Planet. Sci. Lett., 59:101-118.

Sun, S.-S., and McDonough, W. F., 1989. Chemical and isotopic systematics of oceanic basalts: implications for mantle composition and processes. In Saunders, A. D., and Norry, M. J. (Eds.), Magmatism in the Ocean Basins. Geol. Soc. Spec. Publ. London, 42:313-345.

Taylor, B., Fujioka, K., et al., 1990. Proc. ODP, Init. Repts., 126: College Station, TX (Ocean Drilling Program).

von Huene, R., Langseth, M., Nasu, N., and Okada, H., 1980. Summary, Japan Trench transect. In von Huene, R., Nasu, N., et al., Init. Repts. DSDP, 56, 57 (Pt. 1): Washington (U.S. Govt. Printing Office), 473-488.

Wood, D. A., Marsh, N. G., Tarney, J., Joron, L. J., Fryer, P., and Treuil, M., 1982. Geochemistry of igneous rocks recovered from a transect across the Mariana Trough, arc, fore-arc, and trench, Sites 453 through 461, Deep Sea Drilling Project Leg 60. In Hussong, D. M., Uyeda, S., et al., Init. Repts. DSDP, Washington (U.S. Govt. Printing Office), 611-645.

Date of initial receipt: 1 October 1990

Date of acceptance: 19 July 1991

Ms 125B-130 
Table 3. Rare earth element data and selected chondrite-normalized ratios.

\begin{tabular}{|c|c|c|c|c|c|c|c|c|c|c|c|}
\hline Sample number & 2 & 4 & 5 & 8 & $9 b$ & $9 \mathrm{c}$ & $9 \mathrm{e}$ & 10 & $11 a$ & & \\
\hline Hole & $778 \mathrm{~A}$ & $778 \mathrm{~A}$ & 778 & $778 \mathrm{~A}$ & $779 \mathrm{~A}$ & $779 \mathrm{~A}$ & $779 \mathrm{~A}$ & $778 \mathrm{~A}$ & $779 \mathrm{~A}$ & Standard & \\
\hline Core, section & $5 R-1$ & 9R-CC & $11 \mathrm{R}-1$ & 13R-CC & $31 \mathrm{R}-2$ & $31 \mathrm{R}-2$ & 31R-CC & $11 \mathrm{R}-1$ & 9R-1 & deviation & Norm. \\
\hline Interval, (cm) & $7-10$ & $9-12$ & $5-7$ & $4-6$ & $0-4$ & $103-105$ & $25-27$ & $0-3$ & $106-108$ & $(\%)^{\mathrm{a}}$ & factor $^{b}$ \\
\hline \multicolumn{12}{|l|}{ (ppm) } \\
\hline $\mathrm{La}$ & 1.05 & n.a. & n.a. & n.a. & 2.62 & 2.99 & 2.38 & n.a. & 6.34 & n.a. & 0.315 \\
\hline $\mathrm{Ce}$ & 2.92 & 5.64 & 6.72 & 10.08 & 8.62 & 9.57 & 9.63 & 17.28 & 21.30 & 1.9 & 0.813 \\
\hline $\mathrm{Nd}$ & 2.47 & 5.18 & 5.90 & 9.32 & 7.98 & 8.85 & 8.97 & 16.92 & 18.18 & 1.7 & 0.597 \\
\hline Sm & 0.77 & 1.89 & 2.25 & 3.11 & 2.86 & 3.25 & 3.33 & 6.22 & 6.03 & 1.9 & 0.192 \\
\hline $\mathrm{Eu}$ & 0.25 & 0.80 & 0.86 & 1.17 & 1.11 & 1.17 & 1.13 & 2.08 & 2.09 & 0.5 & 0.072 \\
\hline Gd & 1.09 & 2.74 & 3.03 & 4.27 & 3.97 & 4.58 & 4.67 & 8.41 & 7.67 & 0.4 & 0.259 \\
\hline Dy & 1.33 & 3.27 & 3.76 & 4.61 & 4.91 & 5.59 & 5.82 & 10.55 & 8.88 & 1.6 & 0.325 \\
\hline $\mathrm{Er}$ & 0.97 & 2.10 & 2.48 & 2.94 & 3.20 & 3.67 & 3.82 & 7.15 & 5.25 & 1.2 & 0.214 \\
\hline $\mathrm{Yb}$ & 1.09 & 2.05 & 2.56 & 2.76 & 3.18 & 3.69 & 3.71 & 7.22 & 4.78 & 1.6 & 0.208 \\
\hline Lu & 0.17 & 0.31 & 0.41 & 0.42 & 0.50 & 0.58 & 0.57 & 1.07 & 0.66 & 1.9 & 0.032 \\
\hline \multicolumn{12}{|c|}{ Selected chondrite-normalized ratios } \\
\hline$(\mathrm{Ce} / \mathrm{Yb})_{\mathrm{N}}$ & 0.69 & 0.70 & 0.67 & 0.93 & 0.69 & 0.66 & 0.66 & 1.14 & 0.61 & & \\
\hline$(\mathrm{Ce} / \mathrm{Sm})_{\mathrm{N}}$ & 0.90 & 0.70 & 0.71 & 0.76 & 0.71 & 0.69 & 0.68 & 0.83 & 0.66 & & \\
\hline$(\mathrm{Sm} / \mathrm{Lu})_{\mathrm{N}}$ & 0.76 & 1.01 & 0.93 & 1.24 & 0.97 & 0.95 & 0.98 & 1.53 & 0.98 & & \\
\hline$(\mathrm{Gd} / \mathrm{Lu})_{\mathrm{N}}$ & 0.80 & 1.09 & 0.93 & 1.25 & 1.00 & 0.99 & 1.01 & 1.44 & 0.98 & & \\
\hline$(\mathrm{Dy} / \mathrm{Lu})_{\mathrm{N}}$ & 0.77 & 1.04 & 0.92 & 1.08 & 0.98 & 0.96 & 1.01 & 1.33 & 0.98 & & \\
\hline
\end{tabular}

Notes: Data determined by directly coupled plasma (DCP), at Lamont-Doherty Geological Observatory, analyst L. Johnson. n.a. = La values not determined. ${ }^{2}$ Percentage of standard deviation ([1 s.d./average $] \times 100$ ) for four analyses of a Mid-Atlantic Ridge basalt.

${ }^{\mathrm{b}}$ Chondrite factor used for normalization in Figure 2. 